\title{
Ethosomal nanocarriers: the impact of constituents and formulation techniques on ethosomal properties, in vivo studies, and clinical trials
}

This article was published in the following Dove Press journal:

International Journal of Nanomedicine

25 May 2016

Number of times this article has been viewed

\author{
Ibrahim M Abdulbaqi \\ Yusrida Darwis \\ Nurzalina Abdul Karim \\ Khan \\ Reem Abou Assi \\ Arshad A Khan
}

School of Pharmaceutical Sciences, Universiti Sains Malaysia, Penang, Malaysia
Correspondence: Yusrida Darwis School of Pharmaceutical Sciences, Universiti Sains Malaysia, II 800 Penang, Malaysia

Tel +6046534588

Fax +6046570017

Email yusrida@usm.my

\begin{abstract}
Ethosomal systems are novel lipid vesicular carriers containing a relatively high percentage of ethanol. These nanocarriers are especially designed for the efficient delivery of therapeutic agents with different physicochemical properties into deep skin layers and across the skin. Ethosomes have undergone extensive research since they were invented in 1996; new compounds were added to their initial formula, which led to the production of new types of ethosomal systems. Different preparation techniques are used in the preparation of these novel carriers. For ease of application and stability, ethosomal dispersions are incorporated into gels, patches, and creams. Highly diverse in vivo models are used to evaluate their efficacy in der$\mathrm{mal} /$ transdermal delivery, in addition to clinical trials. This article provides a detailed review of the ethosomal systems and categorizes them on the basis of their constituents to classical ethosomes, binary ethosomes, and transethosomes. The differences among these systems are discussed from several perspectives, including the formulation, size, $\zeta$-potential (zeta potential), entrapment efficiency, skin-permeation properties, and stability. This paper gives a detailed review on the effects of ethosomal system constituents, preparation methods, and their significant roles in determining the final properties of these nanocarriers. Furthermore, the novel pharmaceutical dosage forms of ethosomal gels, patches, and creams are highlighted. The article also provides detailed information regarding the in vivo studies and clinical trials conducted for the evaluation of these vesicular systems.
\end{abstract}

Keywords: ethosomes, transdermal, lipid-based vesicles, delivery systems

\section{Introduction}

The skin is the largest and most easily accessible organ of the body; it serves as a potential route of drug administration for systemic effects. However, the outer layer of the skin, the stratum corneum, represents the most resistible barrier to drug penetration across the skin, which limits the transdermal bioavailability of drugs. Therefore, special carriers are required to combat the natural skin barrier to deliver drug molecules with different physicochemical properties to the systemic circulation.

Transdermal drug-delivery systems offer many advantages, such as avoidance of first-pass metabolism by the liver, controlled delivery of drugs, reduced dosing frequency, and improved patient compliance, as they are noninvasive and can be selfadministered. ${ }^{1,2}$ The first transdermal patch containing scopolamine for the treatment of motion sickness was approved in the US in 1979.

A new era of research in this field was opened with the use of liposomes for the topical delivery of triamcinolone, ${ }^{3}$ and since then a wide range of novel lipid-based vesicular systems have been developed. Deformable or elastic liposomes, which are 


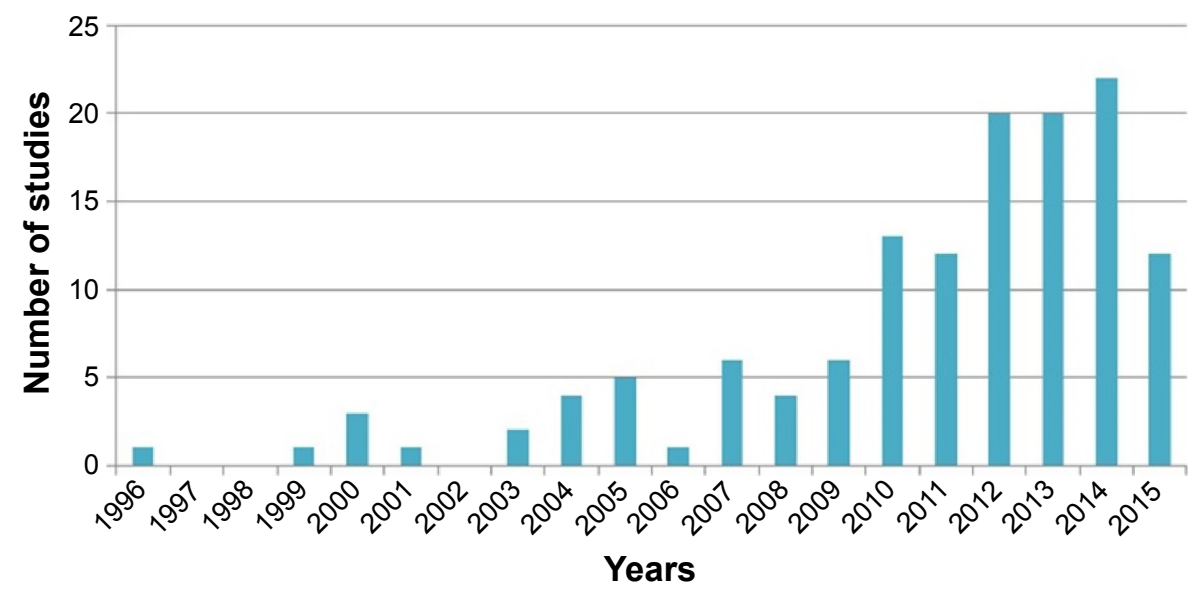

Figure I Ethosomal studies covered by this review, and their annual distribution from July 1996 to November 2015.

currently known as transfersomes, were introduced by Cevc and Blume in $1992^{4}$ and followed by the innovative work of Touitou et al, which led to the discovery of a novel lipid vesicular system called ethosomes. Ethosomal systems differ from liposomes because they contain relatively high concentrations of ethanol, in addition to phospholipids and water. ${ }^{5,6}$ New generations of ethosomal systems have been introduced since then by adding other compounds to the basic ethosomal formula in an attempt to enhance vesicular characteristics and skin permeation. However, to date, there has been no clear distinction among the classical ethosomes and their newer generations. This article provides a detailed review of ethosomal systems and identifies the different types of these vesicles based on the compounds used in their production and the impact of these compounds on ethosomal properties. Additionally, this article also highlights the ethosome preparation methods and pharmaceutical dosage forms, as well as the in vivo studies and clinical trials conducted on these promising nanocarriers for dermal/transdermal delivery. Figure 1 illustrates the number of published articles covered by this review and their annual distribution over a period of almost 2 decades since the development of ethosomes in 1996 till November 2015.

\section{Ethosomal system types}

Figure 2 illustrates the three types of ethosomal systems, classified on the basis of their compositions.

\section{Classical ethosomes}

Classical ethosomes are a modification of classical liposomes and are composed of phospholipids, a high concentration of ethanol up to $45 \% \mathrm{w} / \mathrm{w}$, and water. Classical ethosomes were reported to be superior over classical liposomes for transdermal drug delivery because they were smaller and had negative $\zeta$-potential and higher entrapment efficiency. Moreover, classical ethosomes showed better skin permeation and stability profiles compared to classical liposomes. ${ }^{6-8}$ The molecular weights of drugs entrapped in classical ethosomes have ranged from $130.077 \mathrm{Da}$ to $24 \mathrm{kDa} .{ }^{9,10}$

\section{Binary ethosomes}

Binary ethosomes were introduced by Zhou et al. ${ }^{11}$ Basically, they were developed by adding another type of alcohol to the classical ethosomes. The most commonly used alcohols in

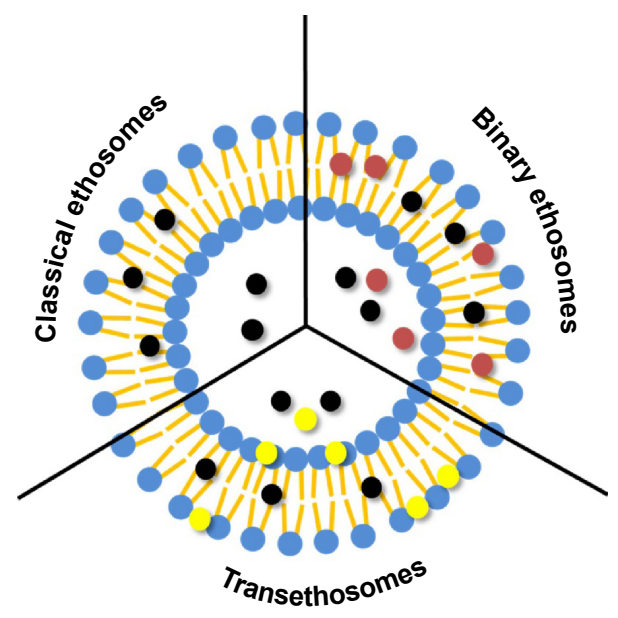

Phospholipid molecule

Ethanol

Propylene glycol or other alcohol

Edge activator or penetration enhancer

Figure $\mathbf{2}$ Schematic representation of the different types of ethosomal systems. 
Table I Comparison of classical ethosomes, binary ethosomes, and transethosomes in their initial suspension form

\begin{tabular}{llll}
\hline Parameter & Classical ethosomes & Binary ethosomes & Transethosomes \\
\hline Composition & I. Phospholipids & I. Phospholipids & I. Phospholipids \\
& 2. Ethanol & 2. Ethanol & 2. Ethanol \\
& 3. Stabilizer & 3. Propylene glycol (PG) or other & 3. Edge activator (surfactant) or penetration \\
enhancer & alcohol & 4. Charge inducer \\
& 4. Charge inducer & 4. Charge inducer & 5. Water \\
& 5. Water & 5. Water & 6. Drug/agent \\
6. Drug/agent & 6. Drug/agent & Regular or irregular spherical shapes \\
Morphology & Spherical & Spherical & Size based on type and concentration of \\
Size & Smaller than the classical & Equal to or smaller than classical & penetration enhancer or edge activator used \\
C-Potential & liposomes & ethosomes & Positively or negatively charged \\
Entrapment & Negatively charged & Negatively charged & Typically higher than classical ethosomes \\
efficiency & Higher than classical liposomes & Typically higher than classical & \\
Skin permeation & typically higher than classical & Typically equal to or higher than & Typically higher than classical ethosomes \\
& liposomes & classical ethosomes &
\end{tabular}

binary ethosomes are propylene glycol (PG) and isopropyl alcohol (IPA). ${ }^{12-16}$

\section{Transethosomes}

Transethosomes are the new generation of ethosomal systems and were first reported by Song et al in $2012 .{ }^{17}$ This ethosomal system contains the basic components of classical ethosomes and an additional compound, such as a penetration enhancer or an edge activator (surfactant) in their formula. These novel vesicles were developed in an attempt to combine the advantages of classical ethosomes and deformable liposomes (transfersomes) in one formula to produce transethosomes. Many researchers have reported superior properties of transethosomes over classical ethosomes. ${ }^{17-30}$ Different types of edge activators and penetration enhancers have been investigated to produce ethosomal systems with better characteristics. Transethosomes were reported to entrap drugs with molecular weights ranging from 130.077 Da to 200-325 kDa. ${ }^{18,21}$ Table 1 shows the comparison of classical ethosome, binary ethosome, and transethosome properties in their initial suspension form.

\section{Effects of materials used on ethosomal system properties Ethanol}

Ethanol is an efficient penetration enhancer. ${ }^{31}$ It plays an important role in ethosomal systems by giving the vesicles unique characteristics in terms of size, $\zeta$-potential, stability, entrapment efficacy, and enhanced skin permeability. Concentrations of ethanol in ethosomal systems have been reported to be $\sim 10 \%-50 \%{ }^{6,32}$ Many researchers concluded that when the concentration of ethanol is increased, the size of the ethosomes would decrease. ${ }^{6,12,33-38}$ Bendas and Tadros found that the mean vesicle diameter of an ethosomal formulation containing $40 \%$ ethanol was $44.6 \%$ smaller than the classical liposomal formulation, which had no ethanol. ${ }^{39}$ However, increasing ethanol concentration beyond the optimum level would cause the bilayer to be leaky and lead to a slight increase in vesicular size and severe decrease in entrapment efficacy, and by further increasing in ethanol concentration it would solubilize the vesicles. Some studies have suggested that high concentrations of ethanol causes interpenetration of the ethanol hydrocarbon chain, which leads to a reduction in vesicular membrane thickness and hence reduces vesicular size. Other researchers have proposed that ethanol modifies the net charge of the systems into some degree of steric stabilization, which could lead to a decrease in mean vesicle size..$^{23,36,37,39-41}$

Vesicular charge is an important parameter that can influence vesicular properties, such as stability and vesicleskin interaction. The high ethanol concentration in ethosomes has shifted the vesicular charge from positive to negative. ${ }^{6,42}$ Dayan and Touitou found that the negative charge of the empty ethosomes increases with increasing ethanol concentration. ${ }^{43}$ Ethanol acts as a negative charge provider for the surface of ethosomes, thereby avoiding aggregation of the vesicular system due to electrostatic repulsion. Additionally, ethanol was also reported to have stabilizing effects. ${ }^{40,44}$ Ethanol also has a significant effect on ethosomal system entrapment efficiency, and in general increasing ethanol concentration will increase entrapment efficiency. ${ }^{45}$ This effect applies to molecules of varying lipophilicities, whereby ethanol increases the solubility of 
the lipophilic and amphiphilic drugs and hence increases drug loading. This relationship was found to be linear, with ethanol concentrations between $20 \%$ and $40 \%{ }^{46}$ For this reason, ethanol concentration should be optimized during the formulation process, as at low concentrations entrapment efficacy will be minimal, and at very high concentrations ethosomal membrane will be more permeable because phospholipids can easily be dissolved in ethanol, leading to a significant reduction in entrapment efficacy.

\section{Phospholipids}

Phospholipids from different sources have been used in ethosomal system formulation. The selection of phospholipid type and concentration for the formulation are important factors during the development of ethosomal system because they will influence the size, entrapment efficacy, $\zeta$-potential, stability, and penetration properties of the vesicles. The different types of phospholipids used in the preparation of ethosomal systems are summarized in Table 2.

Prasanthi and Lakshmi used three phospholipid types (Phospholipon $90 \mathrm{H}$ and $80 \mathrm{H}$ and soy phosphatidylcholine) in the preparation of ethosomal systems of alfuzosin hydrochloride ${ }^{46}$ and tolterodine tartrate ${ }^{47}$ and found that the phospholipid type had a significant effect on the ethosomal size, but not the entrapment efficiency. Shen et al found that the transethosomes prepared by either Lipoid S100 or SPC50 were smaller than those produced by Lipoid E80, and the phospholipids with higher phosphatidylcholine content led to the production of stabler vesicles. ${ }^{27}$ Highly negatively charged vesicles were produced by the incorporation of DPPG (1,2-dipalmitoyl-sn-glycero-3-phosphatidylglycerol) in the ethosomal formulation, ${ }^{48}$ while cationic ethosomal vesicles were produced by using a cationic lipid, such as DOTAP (1,2dioleoyl-3-trimethylammonium-propane [chloride salt]). ${ }^{22}$

In general, the concentration range of phospholipids in an ethosomal formulation is $0.5 \%-5 \%{ }^{24}$ Increasing phospholipid concentration will increase vesicular size slightly or moderately, ${ }^{32,34,64}$ but will increase entrapment efficiency significantly. However, the relationship is true only until a certain concentration, whereby further increment in phospholipid concentration will have no effect on entrapment efficiency. ${ }^{38}$

\section{Cholesterol}

Cholesterol is a rigid steroid molecule, and its incorporation in ethosomal systems enhances the stability and entrapment

Table 2 Phospholipids used in ethosomal formulations

\begin{tabular}{|c|c|c|}
\hline Phospholipid name/brand & Composition and source & Reference(s) \\
\hline Phospholipon 90G & Phosphatidylcholine from soybean (90\%), granules & $37,49,50$ \\
\hline Phospholipon $90 \mathrm{H}$ & Hydrogenated phosphatidylcholine from soybean (90\%), powder & 51 \\
\hline Phospholipon $80 \mathrm{H}$ & $\begin{array}{l}\text { Hydrogenated phospholipids from soybean with } 70 \% \text { phosphatidylcholine, } \\
\text { powder }\end{array}$ & 46 \\
\hline NAT 8539 & $\begin{array}{l}\text { Contained phosphatidylcholine ( } 73 \%-79 \%) \text {, lysophosphatidylcholine (up to } 6 \% \text { ), } \\
\text { cephalin (up to } 4 \% \text { ), and phosphatidic acid (up to } 6 \% \text { ) of the dry residue; natural } \\
\text { oils and sterol up to } 6 \% \text {; and ethanol }(23 \%-27 \%)\end{array}$ & 52 \\
\hline Dipalmitoylphosphatidylcholine (DPPC) & I,2-Dipalmitoyl-rac-glycero-3-phosphocholine, 99\%, powder & 53 \\
\hline Lipoid SI00 & Phosphatidylcholine from soybean, agglomerates & $9,17,54,55$ \\
\hline Lipoid S75-3 & Phosphatidylcholine content (70\%-75\%), from soybean & 56 \\
\hline Lipoid S75 & Phosphatidylcholine content (68\%-73\%), from soybean & 16 \\
\hline Lipoid E80 & Phosphatidylcholine content (8I.7\%), from egg yolk, agglomerates & 27,57 \\
\hline Phosphatidylethanolamine (PE) & $\begin{array}{l}\text { 3-sn-Phosphatidylethanolamine, } \geq 98 \% \text {, from bovine/sheep brain, lyophilized } \\
\text { powder }\end{array}$ & 58 \\
\hline L- $\alpha$-Phosphatidylcholine (PC) & $\begin{array}{l}\text { I,2-Diacyl-sn-glycero-3-phosphocholine, } \geq 99 \% \text {, from soybean/egg yolk, } \\
\text { lyophilized powder }\end{array}$ & $24,59,60$ \\
\hline $\begin{array}{l}\text { POPC (I-palmitoyl-2-oleoyl-sn-glycero-3- } \\
\text { phosphocholine) }\end{array}$ & $\begin{array}{l}\text { I-Hexadecanoyl-2-(9Z-octadecenoyl)-sn-glycero-3-phosphocholine, }>99 \% \text {, } \\
\text { synthetic, powder }\end{array}$ & 61,62 \\
\hline $\begin{array}{l}\text { DPPG (I,2-dipalmitoyl-sn-glycero-3- } \\
\text { phosphatidylglycerol) }\end{array}$ & I,2-Dipalmitoyl-sn-glycero-3-phospho-(I'-rac-glycerol) (sodium salt), powder & 48 \\
\hline Coatsome ${ }^{\circledR}$ FE-608ISU5 POPE-NHS & N-(Succinimidyloxy-glutaryl)-L- $\alpha$-phosphatidylethanolamine, I-palmitoyl-2-oleoyl & 21,22 \\
\hline $\begin{array}{l}\text { DOTAP (I,2-dioleoyl-3- } \\
\text { trimethylammonium-propane [chloride salt]) }\end{array}$ & $\begin{array}{l}\text { I,2-Dioleoyl-3-trimethylammonium-propane (chloride salt), powder or ethanol } \\
\text { solution }\end{array}$ & 22 \\
\hline Phospholipon 50 & $\begin{array}{l}\text { Lecithin from soy purified phosphatidylcholine, concentration } 45 \% \text {, rich in linoleic } \\
\text { acid }(65 \%) \text { and palmitic acid }(-20 \%) \text {, solid wax }\end{array}$ & 63 \\
\hline SPC50 & Phosphatidylcholine content $(50.3 \%)$, from soybean & 27 \\
\hline
\end{tabular}


efficiency of drugs. It prevents leakage and reduces vesicular permeability and vesicular fusion. Generally, it is used at a concentration of $<3 \%,{ }^{59}$ but in some formulations it was used up to $70 \%$ of the total phospholipid concentration in the formulation. ${ }^{24,33}$ Several studies have reported that cholesterol increased the vesicular size of ethosomal systems. ${ }^{24,33,39,65}$ López-Pinto et al found that ethosomal size increased from $136 \pm 42 \mathrm{~nm}$ to $230 \pm 27 \mathrm{~nm}$ when $25.87 \mathrm{mM}$ of cholesterol was used in the formulation. ${ }^{33}$ Another study reported that the increment of cholesterol concentration from $0 \%$ to $0.15 \%$ $\mathrm{w} / \mathrm{w}$ caused vesicular size to increase from $102 \pm 13 \mathrm{~nm}$ to $152 \pm 12 \mathrm{~nm} .{ }^{65}$ However, only one study has found that cholesterol had no stabilization effects on the ethosomes. The authors used phosphatidylethanolamine and 15\% ethanol in the formulation. ${ }^{23}$ López-Pinto et al found that incorporation of cholesterol in the ethosomal formulation increased the vesicular stability and rigidity. However, in vitro studies using Franz diffusion cells and confocal laser-scanning microscopy showed that these multilamellar vesicles (MLVs) were not able to pass across the stratum corneum due to the higher rigidity, and hence it was more difficult for the drug to permeate across the skin. ${ }^{33}$ The increased rigidity (ie, decreased elasticity) of the ethosomal vesicles upon the addition of cholesterol was also reported by other researchers. ${ }^{24,65}$

\section{Dicetyl phosphate}

Dicetyl phosphate is commonly used to prevent aggregation of the vesicles and enhance the stability of the formula. It is used at concentrations between $8 \%$ and $20 \%$ of the total phospholipid concentration in the ethosomal formulation. Maestrelli et al reported that all ethosomal formulations containing dicetyl phosphate produced vesicles with sharply negative $\zeta$-potential. ${ }^{66}$ However, the effects of dicetyl phosphate on other ethosomal system properties are still unclear.

\section{Stearylamine}

Stearylamine is a positive-charge agent, and has been used in ethosomal formulations in two studies. The first study involved an ethosomal system consisting of phosphatidylc holine:cholesterol:stearylamine at a molar ratio of 2:1:1 and loaded with mycophenolic acid. The addition of stearylamine to the ethosomal formulation caused a great increase in vesicular size and decrease in entrapment efficiency, and change in the $\zeta$-potential charge from negative to positive which lead to aggregation of the vesicles within 1 week. The authors attributed all these effects to the incompatibility of the positive charge of stearylamine with the negative charges of soy phosphatidylcholine and mycophenolic acid. ${ }^{24}$ The second study compared the in vitro permeation of two types of ethosome-encapsulated vancomycin hydrochloride with and without stearylamine. The quantity and the transdermal flux of the drug delivered after 12 hours of the negatively charged ethosomes was found to be significantly higher than the positively charged ethosomes. The lower permeation of the positively charged ethosomes was due to the shielding effect of stearylamine and the competition of the positively charged stearylamine with positively charged vancomycin hydrochloride. Stearylamine penetrates the skin easily because it has smaller molecular weight (296.5 Da) compared to vancomycin hydrochloride (1,458.7 Da). Therefore, stearylamine will cross the skin more easily than vancomycin hydrochloride. ${ }^{67}$

\section{Other alcohols}

Other alcohols, such as PG and IPA, are also used in the preparation of binary ethosomes along with ethanol.

\section{Propylene glycol}

PG is a widely used penetration enhancer. It is used in the preparation of binary ethosomes at a concentration range of $5 \%-20 \%$ and found to influence the ethosomal properties of size, entrapment efficiency, permeation, and stability. Incorporation of PG in ethosomal systems will lead to further reduction in particle size in comparison to systems without PG. Significant decrease in particle size from $103.7 \pm 0.9 \mathrm{~nm}$ to $76.3 \pm 0.5 \mathrm{~nm}$ was achieved when PG concentration was increased from $0 \%$ to $20 \% \mathrm{v} / \mathrm{v} .{ }^{13}$

Zhou et al observed that the entrapment efficiency of sophoridine, matrine, sophocarpine, and lehmanine extracted from Sophora alopecuroides increased significantly when PG was incorporated into the ethosomal system with a ratio of ethanol to PG of 1:1 (total alcohol 45\%). ${ }^{11}$ Other researchers have suggested that the presence of ethanol and PG in ethosomes provides better solubility of drugs, and hence higher entrapment efficiency and improved drug distribution throughout the vesicle. ${ }^{14}$ In vitro drug-permeation studies using Franz diffusion cells found that there was no significant difference between classical ethosomes and binary ethosomes in tacrolimus deposition in the stratum corneum. It was also reported that increasing PG concentration in ethosomes from $0 \%$ to $20 \% \mathrm{v} / \mathrm{v}$ decreased the amount of tacrolimus deposition in the epidermis from $2.23 \pm 0.10 \mu \mathrm{g} /$ $\mathrm{m}^{2}$ to $1.48 \pm 0.04 \mu \mathrm{g} / \mathrm{m}^{2}$. Additionally, vesicles containing PG only at a concentration of $30 \% \mathrm{v} / \mathrm{v}$ would not increase tacrolimus disposition significantly in the epidermis. In contrast, ethosomes containing ethanol only at a concentration of $30 \% \mathrm{v} / \mathrm{v}$ had the highest drug disposition in the epidermis. 
Therefore, this finding indicated that ethanol has stronger permeation-enhancing effects than PG on stratum corneum. ${ }^{12}$ Zhang et al investigated the effects of different weight ratios of PG to ethanol of 10:0, 9:1, 7:3, 5:5, 3:7, 1:9, and $0: 10$ on the in vitro skin deposition of terbinafine hydrochloride ethosomes. The total percentage of ethanol and/or PG in the ethosomal system was $45 \% \mathrm{v} / \mathrm{w}$. They observed that skin deposition of terbinafine hydrochloride was decreased by increasing PG percentage in the ethosomes. This could have been due to the lower concentration of ethanol in ethosomes, which affected phospholipid bilayer solubility. The highest skin deposition of terbinafine was obtained in ethosomes containing ethanol:PG at a ratio of $7: 3 .{ }^{13}$ Therefore, it can be concluded that the ratio of ethanol:PG should be optimized in binary ethosomes in order to get higher drug permeation. Binary ethosomes were found to be stabler than classical ethosomes when stored at $4^{\circ} \mathrm{C} . .^{11}$

Therefore, it is suggested that PG enhances ethosome stability by increasing the viscosity and antihydrolysis property. ${ }^{12,13}$

\section{Isopropyl alcohol}

Dave et al studied the influence of IPA on the entrapment efficiency and skin permeation of a diclofenac-loaded ethosomal system. Three types of formulations were prepared: classical ethosomes containing $40 \%$ ethanol, binary ethosomes containing 20\% IPA and 20\% ethanol, and a vesicular system containing $40 \%$ IPA. It was found that the vesicular system containing $40 \%$ IPA had better entrapment efficiency (95\%) than the binary ethosomes $(83.8 \%)$. However, this vesicular system had the lowest $(83.2 \%)$ in vitro drug release in 8 hours compared to binary ethosomes $(85.4 \%)$ and classical ethosomes (93\%). Moreover, transdermal drug-flux values through mouse skin showed that the vesicular system had the lowest flux $\left(146 \mu \mathrm{g} / \mathrm{cm}^{2} / \mathrm{h}\right)$ compared to binary ethosomes $\left(159 \mu \mathrm{g} / \mathrm{cm}^{2} / \mathrm{h}\right)$ and classical ethosomes $\left(226.1 \mu \mathrm{g} / \mathrm{cm}^{2} / \mathrm{h}\right)$. It was concluded that IPA had a pronounced effect on entrapment efficiency but less effect on drug release. ${ }^{15}$ Further studies are required to evaluate the influence of IPA or other alcohols on other ethosomal system properties.

\section{Edge activators or penetration enhancers}

The selection of a proper edge activator or penetration enhancer is a critical step in the formulation of transethosomes, as they have profound effects on the properties of the ethosomal system. Table 3 shows a list of edge activators and penetration enhancers and their concentration used in the preparation of transethosomes.

\section{$\mathrm{N}$-Decylmethyl sulfoxide and dimethyl sulfoxide}

$N$-Decylmethyl sulfoxide is a nonionic surfactant known to increase the permeability of some amino acids and the pentapeptide enkephalin across hairless mouse skin. ${ }^{68}$ Ainbinder and Touitou incorporated $N$-decylmethyl sulfoxide at a concentration of $0.35 \%-1 \% \mathrm{w} / \mathrm{w}$ in an ethosomal system of 5-fluorouracil and named it Tumorep DS (tumor-repressive delivery system). The prepared transethosomes were spherical MLVs with a size of $222.2 \pm 18.1 \mathrm{~nm}$. In vitro dermal delivery of 5-fluorouracil from the transethosomes and classical ethosomes was compared using porcine ear skin. Higher drug accumulation in the porcine skin was obtained from transethosomes (7.98\%) compared to classical ethosomes (3.39\%). An in vitro study was also conducted to compare skin delivery of transethosomes with the commercially available skin product Efudex (Valeant Pharmaceuticals, Bridgewater, NJ, USA). Both Tumorep DS and Efudex contained 5-fluorouracil 5\% $\mathrm{w} / \mathrm{w}$. The results revealed that 5-fluorouracil from transethosomes accumulated threefold more $(10.17 \%)$ in the skin than Efudex (3.75\%). ${ }^{18}$ Dimethyl sulfoxide is a well-established penetration enhancer used in topical pharmaceutical formulations. ${ }^{69}$ Ainbinder and Touitou incorporated $10 \%$ dimethyl sulfoxide in transethosomes of 5-fluorouracil instead of $1 \%$ w/w $N$-decylmethyl sulfoxide in Tumorep DS. The in vitro study results showed that the transethosomes had 2.3 times lower drug accumulation in the skin and 2.9 times higher permeation $(109.23 \pm 12.35 \mu \mathrm{g})$ of the drug across the skin than the classical ethosomes $(38 \pm 8.86 \mu \mathrm{g}){ }^{18}$

\section{Tweens and Spans}

Tween 80 is used at concentrations of $10 \%-50 \%$ of total phospholipid concentration in the ethosomal system. Incorporation of Tween 80 in ethosomal systems was reported to reduce vesicular size and enhance system stability and skin-permeation properties. The effects of Tween 80 on the ethosomal system are mainly due to its solubilizing property and the prevention of vesicle fusion. ${ }^{17,19,24,27,70}$ Shen et al used Tween 60 in the formulation of transethosomes of artesunate and febrifugine. However, the formulations were unstable, as needle crystals formed in the formula after 5 days. ${ }^{27}$ Bragagni et al introduced Tween 20 in an ethosomal system of celecoxib at $15 \%$ of the total phospholipid concentration. It was found that Tween 20-containing transethosomes had smaller vesicular size $(258.4 \pm 3.3 \mathrm{~nm})$, higher entrapment efficiency (54.4\%), and better ex vivo skin permeation through human skin compared to transethosomes containing Tween 80 or sodium cholate. ${ }^{19}$ In another study, addition of 
Table 3 Edge activators or penetration enhancers used in the preparation of transethosomes

\begin{tabular}{|c|c|c|c|}
\hline $\begin{array}{l}\text { Edge activator/penetration } \\
\text { enhancer }\end{array}$ & Type & Concentration & Reference(s) \\
\hline N-Decylmethyl sulfoxide & Nonionic surfactant & $0.35 \%-1 \%$ of the total ethosomal system & 18 \\
\hline Dimethyl sulfoxide & Penetration enhancer & $10 \%$ of the total ethosomal system & 18 \\
\hline Tween 80 & Nonionic surfactant & $\begin{array}{l}10 \%-50 \% \text { of the total phospholipid concentration } \\
\text { in the ethosomal system }\end{array}$ & $17,19,24,27,70$ \\
\hline Tween 60 & Nonionic surfactant & $\begin{array}{l}\text { Up to } 50 \% \text { of the total phospholipid concentration } \\
\text { in the ethosomal system }\end{array}$ & 27 \\
\hline Tween 20 & Nonionic surfactant & $\begin{array}{l}15 \%-50 \% \text { of the total phospholipid concentration } \\
\text { in the ethosomal system }\end{array}$ & 19,27 \\
\hline Oleic acid & Penetration enhancer & $0.5 \%-3 \%$ of the total ethosomal system & $17,25,29$ \\
\hline L-Menthol & Penetration enhancer & $5 \%$ of the total ethosomal system & 25 \\
\hline Sodium stearate & Anionic surfactant & $\begin{array}{l}\text { Phosphatidylethanolamine:cholesterol:sodium } \\
\text { stearate at a molar ratio of } 2: 1: 2.5\end{array}$ & 23 \\
\hline Deoxycholic acid & Bile acid/anionic surfactant & $\begin{array}{l}\text { Phosphatidylcholine:cholesterol:deoxycholic acid } \\
\text { at molar ratios of } 2: 1: 1 \text { and } 6: 2: 1\end{array}$ & 24 \\
\hline Sodium deoxycholate & Bile salt/anionic surfactant & $0.8 \% \mathrm{w} / \mathrm{v}$ of the total ethosomal system & 29 \\
\hline Sodium cholate & Bile salt/anionic surfactant & $0.66 \%$ of the total ethosomal system & 19 \\
\hline Sodium taurocholate & Bile salt/anionic surfactant & $0.53 \%$ of the total ethosomal system & 17 \\
\hline Polyethylene glycol 4000 & Surfactant & $\begin{array}{l}\text { Phosphatidylcholine:cholesterol:polyethylene } \\
\text { glycol } 4000 \text { at molar ratios of } 2: 1: 1 \text { and } 6: 2: 1\end{array}$ & 24 \\
\hline $\begin{array}{l}\text { Hexadecyltrimethylammonium } \\
\text { bromide }\end{array}$ & Cationic surfactant & I\% of the total ethosomal system & 20 \\
\hline Cremophor EL-35 & Nonionic surfactant & $0.5 \%-1.5 \%$ of the total ethosomal system & 20 \\
\hline Cremophor RH-40 & Nonionic surfactant & $\begin{array}{l}\text { Up to } 50 \% \text { of the total phospholipid concentration } \\
\text { in the ethosomal system }\end{array}$ & 27 \\
\hline Spans $80,60,40,20$ & Nonionic surfactant & $\begin{array}{l}\text { Up to } 50 \% \text { of the total phospholipid concentration } \\
\text { in the ethosomal system }\end{array}$ & $19,27,30$ \\
\hline $\begin{array}{l}\text { Skin-penetrating and cell-entering } \\
\text { (SPACE) peptide }\end{array}$ & Penetration enhancer & $2-10 \mathrm{mg} / \mathrm{mL}$ & 21,22 \\
\hline Sodium dodecyl sulfate & Anionic surfactant & $0.8 \%$ of the total ethosomal system & 26,29 \\
\hline
\end{tabular}

Tween 20 formed an unstable formulation. ${ }^{27}$ Spans 80, 60, and 40 were not successful in producing homogeneous and stable transethosomes. ${ }^{19,27}$ Only Span 20 was used successfully in the preparation of transethosomes of caffeine and vitamin E. ${ }^{30}$

\section{Oleic acid}

Oleic acid influences vesicular size, elasticity, $\zeta$-potential, and skin-permeation properties by increasing the fluidity of the stratum corneum. ${ }^{17,25,29}$ Song et al used oleic acid as a penetration enhancer at a concentration of $0.5 \%$ and found that transethosomes of voriconazole containing oleic acid were smaller and more elastic than transethosomes containing Tween 80 or sodium taurocholate. Moreover, the transethosomes containing oleic acid had higher negative $\zeta$-potential, skin-permeation rate, and drug disposition in the epidermis/dermis. ${ }^{17} \mathrm{Ma}$ et al found that the entrapment efficiency of imiquimod in transethosomes containing oleic acid $(85.38 \% \pm 1.4 \%)$ was significantly higher than classical ethosomes $(41.93 \% \pm 2.1 \%) .^{29}$

\section{L-Menthol}

L-Menthol was added as a penetration enhancer to transethosomes of ascorbic acid at a concentration of $5 \%$. In vitro studies showed that the cumulative percentage of drug release after 24 hours through a human skin cadaver was higher for transethosomes containing L-menthol (36.5\%) than classical ethosomes $(33.55 \%)$. The authors attributed this effect to L-menthol, which formed a eutectic mixture with the drug, which in turn enhanced drug solubility and altered the barrier properties of the stratum corneum. ${ }^{25}$

\section{Sodium stearate}

Sodium stearate was incorporated in an ethosomal system of 5-aminolevulinic acid consisting of phosphatidylethanolamine: cholesterol:sodium stearate at a ratio of $2: 1: 2.5$. Sodium stearate was used in an attempt to raise the negative charge of the vesicular surface and increase system stability. The addition of sodium stearate caused three main effects: 1) reduced the vesicles from $132.6 \pm 1.9 \mathrm{~nm}$ to $126.4 \pm 2.8 \mathrm{~nm}$, which suggested the insertion of carbon chains of sodium 
stearate into the lipid bilayers; 2) increased the negative surface charge from $-53.0 \pm 0.8 \mathrm{mV}$ to $-70.06 \pm 1.9 \mathrm{mV}$; and 3 ) increased the entrapment efficiency of 5-aminolevulinic acid from $9.09 \% \pm 4.02 \%$ to $66.42 \% \pm 0.34 \%$, which was due to the interaction between the drug and sodium stearate in the lipid bilayers. ${ }^{23}$

\section{Bile acids and salts}

Deoxycholic acid is a bile acid used in the preparation of mycophenolic acid transethosomes and has been found to cause significant increase in vesicular size (ie, from $258 \pm 5$ to $546 \pm 33 \mathrm{~nm}$ ) and entrapment efficiency, which could be due to high interbilayer distance caused by electrostatic repulsive force. Moreover, it also improved ethosomal system stability, which could be due to an increase in the negative surface charge of the vesicle, and hence prevented vesicular aggregation. ${ }^{24}$ The bile salt of sodium deoxycholate was used in formulating transethosomes of imiquimod at a concentration of $0.8 \% \mathrm{w} / \mathrm{v}$. It was found to decrease ethosomal size significantly - from $190.6 \pm 10 \mathrm{~nm}$ to $92.7 \pm 8.7 \mathrm{~nm}-$ and to increase $\zeta$-potential and entrapment efficiency from $-19.9 \pm 2.7 \mathrm{mV}$ to $-28 \pm 2.4 \mathrm{mV}$ and $41.93 \% \pm 2.1 \%$ to $70.86 \% \pm 1.2 \%$, respectively. ${ }^{29}$ Sodium cholate was used for the preparation of transethosomes of vitamin $\mathrm{E}$ and caffeine. The system was composed of soy phosphatidylcholine:sodium cholate at a molar ratio of $3.75: 1$, and it was found to increase the value of the negatively charged $\zeta$-potential of the vesicles, suggesting better stability. ${ }^{30}$ In another study, it was used at a concentration of $0.66 \%$, but physically unstable vesicles were formed in $<24$ hours. ${ }^{19}$ Sodium taurocholate was used at a concentration of $0.53 \%$ in the preparation of voriconazole-loaded transethosomes and shown to cause higher negative $\zeta$-potential, stabler formulation, better vesicle elasticity, and in vitro permeability through hairless mouse skin compared to classical ethosomes, traditional liposomes, or transfersomes. ${ }^{17}$

\section{Polyethylene glycol 4000}

Only one study has used polyethylene glycol 4000 in transethosomes of mycophenolic acid: these consisted of phosphatidylcholine:cholesterol:polyethylene glycol 4000 at molar ratios of $2: 1: 1$ and $6: 2: 1$. The authors reported that it increased vesicular size, but no results were shown regarding entrapment efficiency, permeation properties, or stability of the ethosomal system. ${ }^{24}$

\section{Hexadecyltrimethylammonium bromide}

Meng et al studied the effects of a cationic surfactant hexadecyltrimethylammonium bromide on transethosomes of testosterone propionate. They found that increasing the concentration of this surfactant from $0 \%$ to $1 \% \mathrm{w} / \mathrm{w}$ would decrease vesicle size and change vesicular charge from negative $(-1.22 \pm 0.89 \mathrm{mV})$ to positive $(9.39 \pm 1 \mathrm{mV})$. It was noted that the addition of only $0.2 \% \mathrm{w} / \mathrm{w}$ of hexadecyltrimethylammonium bromide was sufficient to change the $\zeta$-potential of ethosomal system. ${ }^{20}$ They suggested that this positively charged $\zeta$-potential may enhance the skin-permeation properties of the ethosomal system, due to attraction with the negatively charged skin surface.

\section{Cremophor}

Cremophor is the brand name of a range of nonionic polyethoxylated detergents. Cremophor EL-35 was used in an ethosomal system of testosterone propionate at concentrations of $0.5 \%-1.5 \% \mathrm{w} / \mathrm{w}$. It was found to reduce vesicular size and to increase the solubility of the drug and entrapment efficiency. ${ }^{20}$ Shen et al used Cremophor RH-40 in the formulation of transethosomes of artesunate and febrifugine; however, the vesicles were unstable and needle crystals had formed after 5 days. ${ }^{27}$

\section{Skin-penetrating and cell-entering peptide}

Skin-penetrating and cell-entering (SPACE) peptide is a skinpenetration enhancer discovered through phage display and shown to deliver short interfering RNA (siRNA) and streptavidin into the skin after direct chemical conjugation. ${ }^{71}$ This penetration enhancer was incorporated in transethosomes for the delivery of hyaluronic acid and siRNAs. ${ }^{21,22}$ The authors named these transethosomes SPACE ethosomal system.

The in vitro human skin penetration of hyaluronic acid transethosomes was 7.8 \pm 1 .1-fold higher than buffer solution, 5.9 \pm 2.5 -fold higher than buffer-ethanol solution, and 3.2 \pm 0.6 -fold higher than classical ethosomes. The penetration enhancement from the SPACE-peptide transethosomes was dependent on the concentration of the SPACE peptide in the formula. ${ }^{21}$

siRNA-loaded transethosomes were named SPACE peptide-decorated cationic ethosomes (DOTAP-SPACE ethosomal system). The formulation contained SPACEconjugated siRNA encapsulated in a carrier made up of a cationic lipid (DOTAP), cholesterol, SPACE-conjugated lipids (SPACE peptide - POPE) and free SPACE peptide; all were suspended in buffer-ethanol solution $45 \% \mathrm{v} / \mathrm{v}$. The SPACE peptide was at three places: direct conjugation to siRNA, direct conjugation to the vesicular surface, and in free form. In vitro porcine skin-penetration studies showed that the penetration of siRNA transethosomes (ie, DOTAP-SPACE 
ethosomal system) was $6.3 \pm 1.7$-fold higher than the penetration of siRNA aqueous solution.

\section{Sodium dodecyl sulfate}

Sodium dodecyl sulfate is an anionic surfactant and has been used at a concentration of $0.8 \% \mathrm{w} / \mathrm{v}$ in the preparation of transethosomes of ketoconazole ${ }^{26}$ and imiquimod. ${ }^{29}$ The results showed that sodium dodecyl sulfate significantly reduced the size, increased the entrapment efficiency and the $\zeta$-potential, and enhanced the in vitro and in vivo skinpermeation properties of ethosomal systems.

\section{Drug/agent effects on ethosomal system properties}

The most important factor to consider in ethosomal formulations is the nature or physicochemical properties of the drug/agent that is going to be incorporated. This is because the drug/agent may affect the properties of the ethosomal systems, especially particle size and $\zeta$-potential.

Lodzki et al observed the vesicular size of an ethosomal system decreased when trihexyphenidyl hydrochloride was incorporated in the system. The average diameter of the blank ethosomes was $154 \pm 15 \mathrm{~nm}$ and decreased to $109 \pm 6 \mathrm{~nm}$ after drug loading. The authors attributed this effect to the surfaceactive properties of the incorporated drug. ${ }^{43}$ Reduction in vesicular size has also been reported in ethosomal systems loaded with buspirone hydrochloride, ${ }^{72}$ cromolyn sodium, ${ }^{36}$ and diclofenac sodium. ${ }^{63}$

In contrast, Paolino et al noticed a significant increase in vesicular size following the incorporation of paclitaxel in an ethosomal system, and this increment was profound with certain formulations. For example, the mean size of blank ethosomes was $131 \pm 13 \mathrm{~nm}$ and increased to $751.3 \pm 38.34 \mathrm{~nm}$ after loading the drug. ${ }^{50}$

In general, ethosomal vesicles tend to have a negative charge. However, some researchers have observed that the drug entrapped in an ethosomal system can shift the vesicular charge from negative to positive. Shumilov and Touitou reported that the charge of an empty ethosomal system was negative $(-8.8 \mathrm{mV})$ and shifted to positive $(7.16 \mathrm{mV})$ after the incorporation of $30 \mathrm{mg}$ buspirone hydrochloride into the ethosomal system. ${ }^{72}$ A similar finding was also observed with trihexyphenidyl hydrochloride $0.5 \% \mathrm{w} / \mathrm{w}$, where the empty ethosomes' negative charge $(-4.5 \mathrm{mV})$ shifted to a positive charge $(4.8 \mathrm{mV})$. This effect was dependent on the concentration of the trihexyphenidyl hydrochloride added. Increasing the percentage of the drug to $1 \%$ and $3 \% \mathrm{w} / \mathrm{w}$ resulted in a corresponding increase in $\zeta$-potential values of
$7.2 \mathrm{mV}$ and $10.4 \mathrm{mV}$, respectively. ${ }^{43}$ The vesicular charge shifting from negative to positive was also reported with an ethosomal system of a synthetic lipophilic prodrug of acyclovir $\left(\mathrm{ACV}-\mathrm{C}_{16}\right)$. This effect was attributed to the addition of a carbonyl group during the synthesis of the prodrug. The carbonyl group acted as an electron-withdrawal group, and hence resulted in $\mathrm{ACV}-\mathrm{C}_{16}$ ethosomes being positively charged. On the contrary, the $\zeta$-potential of the active acyclovir (nonprodrug)-loaded ethosomal system mentioned in the same study was negative $(-22.3 \pm 1.7 \mathrm{mV}) .{ }^{41}$ Rakesh and Anoop reported that the incorporated drug could further increase the negative value of the $\zeta$-potential. The $\zeta$-potential of the blank vesicles was $-9.11 \pm 1.5 \mathrm{mV}$ and increased to $-63.42 \pm 1.3 \mathrm{mV}$ after the incorporation of $1 \%$ w/v cromolyn sodium. ${ }^{36}$ A similar phenomenon was also observed between blank and paclitaxel-loaded ethosomal systems..$^{50}$

\section{Preparation techniques and their effects on ethosomal properties} The classical cold method

This is the simplest and most widely used method for the preparation of ethosomal systems, and if required it could be done under nitrogen protection. ${ }^{64}$ It was introduced by Touitou in 1996, ${ }^{5}$ and involves the preparation of the organic phase and aqueous phase separately. The organic phase is obtained by dissolving the phospholipids (in addition to surfactants or penetration enhancer for transethosomes) in ethanol or mixture of solvents (ethanol/PG) for the preparation of binary ethosomes, ${ }^{13}$ at room temperature, ${ }^{73}$ or at $30^{\circ} \mathrm{C} .{ }^{6}$ The aqueous phase used is either water, ${ }^{44,74,75}$ buffer solution, ${ }^{76,77}$ or normal saline solution. ${ }^{78}$ The aqueous phase is added to the organic phase in a fine stream, ${ }^{6}$ dropwise, ${ }^{41}$ or using a syringe pump at a constant rate of $1^{75}$ or $200 \mu \mathrm{L} / \mathrm{min} .{ }^{64}$ The mixture is stirred at a speed of 700-2,000 rpm, ${ }^{6,75,79,80}$ using an overhead ${ }^{81}$ or magnetic ${ }^{82}$ stirrer. The mixing is done for 5-30 minutes ${ }^{75,83}$ to obtain the required ethosomal suspension. The drug to be incorporated in the ethosomal system will be dissolved in either the aqueous or the organic phase, depending on its physicochemical properties. Figure 3 presents the preparation steps of an ethosomal system using the classical cold method.

\section{The ethanol injection-sonication method}

In this method, the organic phase containing the dissolved phospholipid in ethanol is injected to the aqueous phase, using a syringe system, ${ }^{38}$ at a flow rate of $200 \mu \mathrm{L} / \mathrm{min}$, then homogenized with an ultrasonic probe for 5 minutes. ${ }^{34}$ 


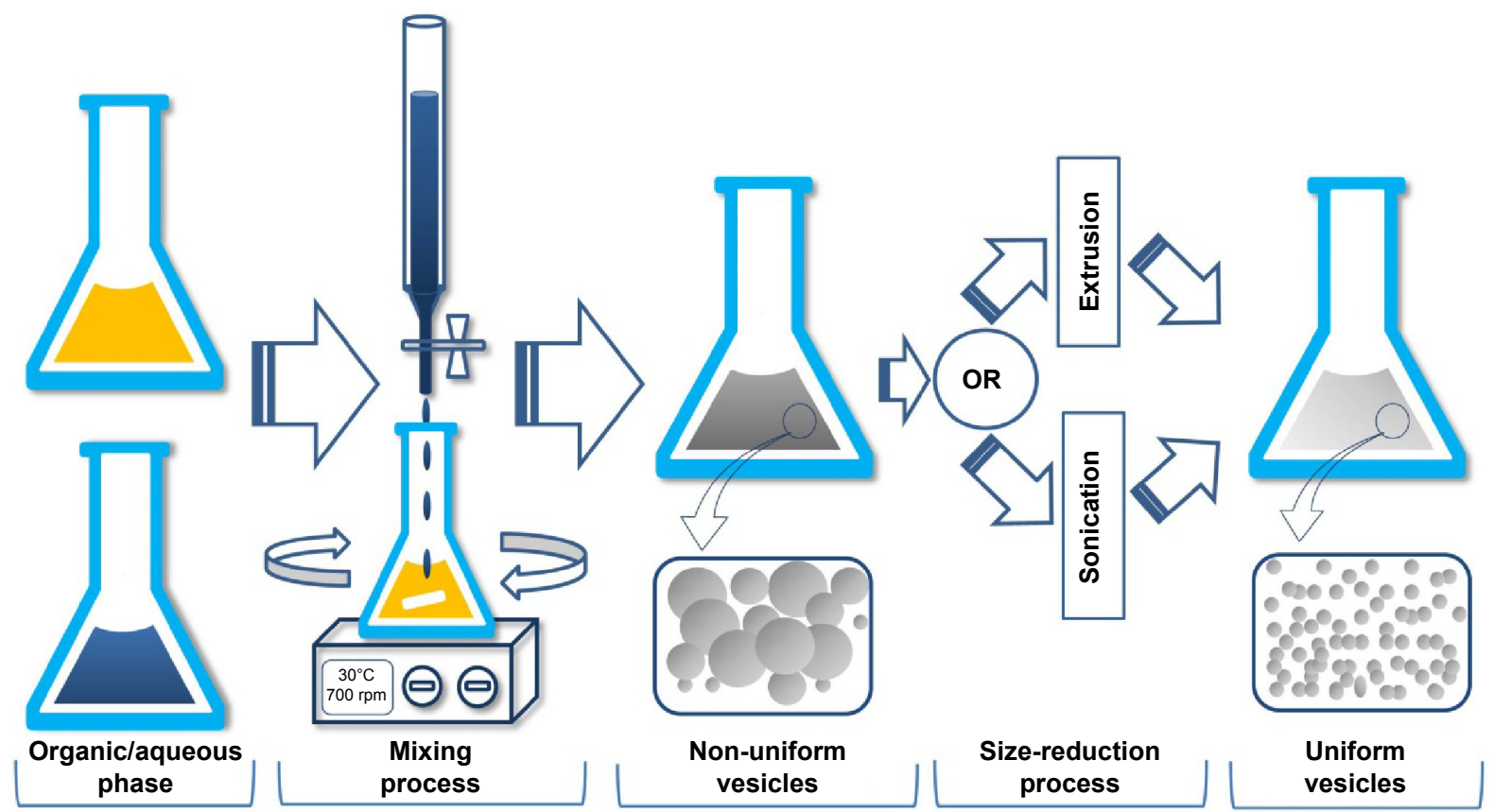

Organic phase:

Classical ethosomes: phospholipids + ethanol

Binary ethosomes: phospholipids + ethanol + (PG or IPA)

Transethosomes: phospholipids + ethanol + surfactant

or penetration enhancer

Aqueous phase:

Water or buffer system

Figure 3 The classical cold method for the preparation of ethosomal systems.

Abbreviations: PG, propylene glycol; IPA, isopropyl alcohol.

\section{The hot method}

This method was first described by the inventor of ethosomes in 1996. ${ }^{5}$ In one vessel, phospholipid is dispersed in water and then placed in a water bath at $40^{\circ} \mathrm{C}$ until a colloidal suspension is obtained. In another vessel, ethanol is heated to $40^{\circ} \mathrm{C}$ and then added dropwise to the phospholipid dispersion under continuous mixing using a mechanical or magnetic stirrer. ${ }^{84}$ The drug is dissolved in either the organic or aqueous phase, based on its hydrophilic/hydrophobic properties.

\section{The thin-film hydration method}

This represents the extension of the conventional liposomepreparation method, but in this method the lipid film is hydrated by a hydroethanolic solution. The phospholipid is first dissolved in chloroform only ${ }^{85}$ or a chloroform-methanol mixture at ratios of $3: 1^{10}$ or $2: 1^{86}$ in a clean, dry, round-bottom flask. Organic solvents are removed by a rotary vacuum evaporator at a temperature above the lipid-phase transition temperature. Then, the traces of the solvents are removed from the deposited lipid film under vacuum overnight. The lipid film is then hydrated with a water-ethanol solution ${ }^{33}$ or phosphate buffered saline-ethanol solution. ${ }^{87}$ During the hydration process, the lipid film is rotated and heated at the required temperature, which depends on the phospholipid property, for 30 minutes, ${ }^{23} 1$ hour, ${ }^{88}$ or 6 hours. ${ }^{86}$

\section{The reverse-phase evaporation method}

This is the least used method and specially designed to produce large unilamellar vesicles. The organic phase is prepared by dissolving the phospholipid in diethyl ether and then mixing it with the aqueous phase at a ratio of $3: 1 \mathrm{v} / \mathrm{v}$ in an ultrasonic bath at $0^{\circ} \mathrm{C}$ for 5 minutes to form a water-inoil emulsion. The organic solvent is removed under reduced pressure to produce a gel, which turns into a colloidal dispersion upon vigorous mechanical agitation. ${ }^{66}$

\section{Transmembrane $\mathrm{pH}$-gradient method}

In all the methods just mentioned, the drug is added in either the organic or the aqueous phase, and it is spontaneously or "passively" loaded in the ethosomal system. In the transmembrane $\mathrm{pH}$-gradient method, the drug is loaded "actively", based on the $\mathrm{pH}$-gradient difference between the acidic interior of the internal phase and the basic exterior of the external phase of the ethosomal system. The concept of this method was first applied in the preparation of liposomes, ${ }^{89,90}$ then it was used by Zhou et $\mathrm{al}^{11}$ and Fan et a ${ }^{91}$ 


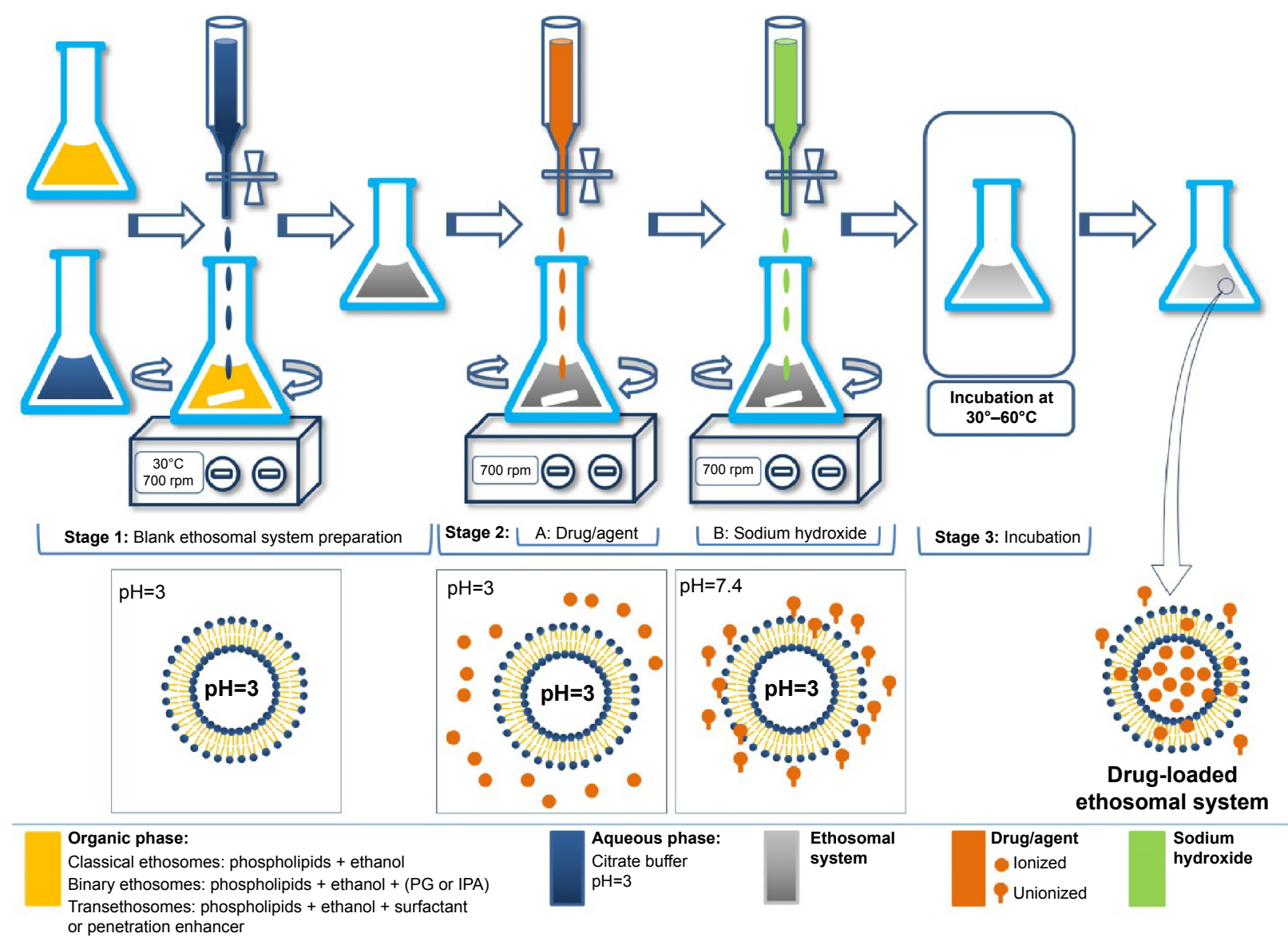

Figure 4 The transmembrane $\mathrm{pH}$-gradient method for the preparation of ethosomal systems. Abbreviations: PG, propylene glycol; IPA, isopropyl alcohol.

in the preparation of ethosomal systems of total alkaloid extracts of $S$. alopecuroides and tetrandrine, respectively. The method is suitable only for water-soluble drugs that have protonizable amine functions. This method involves three stages: preparation of the blank ethosomal system, active loading of the drug, and incubation (last stage).

In the first stage, the empty ethosomal suspension is prepared using any of the aforementioned methods, but the aqueous phase or the hydration process uses an acidic buffer (usually citrate buffer, $\mathrm{pH} 3$ ). The second stage involves the active loading of the drug into the empty ethosomal suspension, followed by continuous stirring. In order to make the external phase more alkaline and to establish the $\mathrm{pH}$ gradient between the acidic internal $(\mathrm{pH} 3)$ and basic external phases of the ethosomal system, an alkali, usually a sodium hydroxide solution of $0.5 \mathrm{M}$, is added to make the external $\mathrm{pH}$ 7.4. In the third stage, the ethosomal system is incubated at a specified time and temperature $\left(30^{\circ} \mathrm{C}-60^{\circ} \mathrm{C}\right)$ to give the opportunity for the unionized drug to actively pass the bilayer of the ethosomal vesicles and get entrapped. ${ }^{11}$ Before preparation of ethosomal systems using this method, some factors need to be taken into consideration, such as the physiochemical properties of the drug/agent to be incorporated, the $\mathrm{pH}$ of the internal and external phases, and the temperature and the duration of the incubation period. The different steps of ethosomal preparation using this method are illustrated in Figure 4.

\section{Ethosomal system size and lamellarity}

Ethosomal nanocarriers are especially designed for topical and transdermal drug delivery, and hence the size and lamellarity of these carriers are of high importance. The size of these vesicles should be reduced to $<200 \mathrm{~nm}$ or $300 \mathrm{~nm}$ to be suitable for this route of administration. ${ }^{14,40,92}$ Therefore, in all the aforementioned methods except the reverse-phase evaporation method, the prepared ethosomal systems are subjected to different further processing to get the required size or lamellarity.

Generally, there are two main techniques used to reduce the size of ethosomal systems: extrusion and sonication processes. Homogenization is sometimes employed, but 
practically it has no effect in reducing vesicular size. The extrusion process is usually done by sequentially extruding the ethosomal system under relatively low pressure for certain times or cycles through polycarbonate membranes of different pore sizes of 50-400 $\mathrm{nm}$. The extrusion is done by either multiple extrusions through one membrane with one pore size or sequential extrusion of the ethosomal system through stacked membranes of different pore sizes. The smaller the pore size of the membrane, the smaller the diameter of the ethosomal system produced. Gu et al reported that the mean sizes of 5-fluorouracil ethosomes extruded through membranes with pore sizes of $50 \mathrm{~nm}$ and $100 \mathrm{~nm}$ were $60 \pm 10 \mathrm{~nm}$ and $110 \pm 13 \mathrm{~nm}$, respectively. ${ }^{93}$ Many commercially available extruders are used for the extrusion process, such as the Lipex ${ }^{\circledR}$ extruder (Transferra Nanosciences, Burnaby, BC, Canada), a hand extruder (EMD Millipore, Billerica, MA, USA) ${ }^{65}$ the Gastight 1001 extruder (Hamilton, Reno, NV, USA), ${ }^{48}$ the Mini-Extruder (Avanti Polar Lipids, Alabaster, AL, USA), ${ }^{94}$ and disposable filters. ${ }^{80}$ The selection of membrane type, pore size, pressure, number of extrusions, filtration times, or cycles should be optimized according to the required properties of the ethosomal system. The result of this process is the production of more uniform ethosomal colloidal suspension of small unilamellar vesicles (SUVs) with lower polydispersity index values.

The sonication method uses either the probe sonicator (the most common) $)^{40}$ or the ultrasonic bath. ${ }^{9}$ This method produces uniform ethosomal suspension of SUVs. Some parameters in this method, ie, sonicator type, voltage, temperature, probe types, time, and number of cycles, should be optimized according to the ethosomal system components and the properties required. Maestrelli et al observed that the size of SUVs obtained by sonication was smaller $(189.3 \pm 13.7 \mathrm{~nm})$ compared to extrusion $(295.8 \pm 33.2 \mathrm{~nm}) .{ }^{66}$ Furthermore, Chen et al reported that the entrapment efficiency of triptolide was increased by increasing the sonication time till it reached a point that had no significant effect. ${ }^{95}$ However, the entrapment efficiency of SUVs obtained by extrusion was higher than that by sonication, which may be attributed to the bigger vesicles. ${ }^{66}$

There is no clear rule for the preparation of ethosomal vesicles with specific lamellarity; generally, all the preparation techniques discussed previously lead to the production of vesicles with diverse sizes and lamellarities ie, MLVs, oligolamellar vesicles, large unilamellar vesicles, and SUVs. Application of size-reduction techniques lead mainly to the production of SUVs. Large unilamellar vesicles are produced by the reversephase evaporation method. Frozen and thawed MLVs, which are bigger than MLVs, are produced by exposing MLVs to a number of alternative cycles (each of 30 seconds) of freezing using liquid nitrogen and thawing in a bath at $58^{\circ} \mathrm{C}$. Frozen and thawed MLVs show lower entrapment efficiency than MLVs despite their size, and they become smaller during storage, because they are less stable. ${ }^{66}$

\section{Ethosomal dosage forms}

The majority of the published articles have studied ethosomal systems in their initial suspension form. Ethosomal suspension contains a high concentration of alcohol, and thus further incorporation of the system in a suitable vehicle for dermal/transdermal delivery has some advantages, ie, preventing ethanol evaporation, prolonging contact time with the skin, enhancing the therapeutic efficacy of the entrapped drug, improving stability and shelf life of the final dosage form, and patient compliance. Ethosomal systems have been incorporated in different vehicles to produce novel pharmaceutical formulations, such as ethosomal gels, transdermal patches, and creams.

\section{Ethosomal gels}

Ethosomal gels are characterized for their $\mathrm{pH}$, viscosity, spreadability, and extrudability. The most commonly used gel-forming agents for incorporating ethosomal systems are Carbopol and hydroxypropyl methylcellulose with all their related grades. These polymers have been shown to be compatible with ethosomal systems, providing the required viscosity and bioadhesive properties. The types of polymers used in the preparation of ethosomal gels and their concentrations are listed in Table 4.

Several researchers have studied the skin-permeation and disposition properties of drugs from ethosomal gels in comparison to the traditional or marketed gels or creams. Puri and Jain compared the in vitro skin-permeation properties of 5-fluorouracil from ethosomal gel and marketed cream using Franz diffusion cell and albino rat skin and found that the transdermal flux of 5-fluorouracil from ethosomal gels was 4.9-fold higher than the marketed cream. Moreover, the skin disposition of the drug from the ethosomal gel was 9.4-fold higher than the marketed cream. ${ }^{32}$ Other researchers found that in vitro transdermal flux of aceclofenac from ethosomal gel was higher $\left(226.1 \mu \mathrm{g} / \mathrm{cm}^{2} / \mathrm{h}\right)$ than Zynac gel $\left(131.1 \mu \mathrm{g} / \mathrm{cm}^{2} / \mathrm{h}\right) .{ }^{15}$ Some authors have reported the same superior properties of ethosomal gels for different drugs/agents over traditional gels. ${ }^{14,18,96}$ Interestingly, it was found that the drug-release rate from the ethosomal suspension was faster than from ethosomal gel, due to the high viscosity of the gel. ${ }^{97-99}$ 
Table 4 Types and concentrations of gel-forming agents used in ethosomal gel preparations

\begin{tabular}{|c|c|c|c|}
\hline \multirow[t]{2}{*}{ Drug/agent } & \multicolumn{2}{|l|}{ Gel-forming agent } & \multirow[t]{2}{*}{ Reference(s) } \\
\hline & Name & Concentration & \\
\hline Amphotericin B & Carbopol 934 & $1 \% w / w$ & 100 \\
\hline Econazole nitrate & Carbopol 934 & $1 \% w / w$ & 40 \\
\hline Ketoconazole & Carbopol 934 & $2 \% \mathrm{w} / \mathrm{w}$ & 84 \\
\hline Lopinavir & Carbopol 934 & $0.8 \% \mathrm{w} / \mathrm{v}$ & 35 \\
\hline Losartan & Carbopol 934 & $0.75 \% \mathrm{w} / \mathrm{v}$ & 96 \\
\hline Meloxicam & Carbopol 934 & $1 \% w / w$ & 101 \\
\hline Testosterone & Carbopol 934 & NM & 102 \\
\hline Tretinoin & Carbopol 934 & $1.5 \% \mathrm{w} / \mathrm{w}$ & 78 \\
\hline Valsartan & Carbopol 934 & NM & 51 \\
\hline 5-Fluorouracil & Carbopol 934P & $1.5 \% \mathrm{w} / \mathrm{w}$ & 32 \\
\hline Aceclofenac & Carbopol 934P & $0.75 \% \mathrm{w} / \mathrm{v}$ & 15 \\
\hline Azelaic acid & Carbopol 934P & $0.75 \% \mathrm{w} / \mathrm{w}$ & 97 \\
\hline Methoxsalen & Carbopol 934P & $2 \% w / w$ & 103 \\
\hline Vinpocetine & Carbopol 934P & $1 \% w / w$ & 104 \\
\hline Clotrimazole & Carbopol 934LR & $1 \% w / v$ & 14 \\
\hline Psoralen & Carbopol 934LR & $1 \% w / v$ & 92 \\
\hline Benzocaine & Carbopol 940 & $0.5 \% \mathrm{w} / \mathrm{w}$ & 66 \\
\hline Black-tea extracts & Carbopol 940 & NM & 28 \\
\hline Buspirone hydrochloride & Carbopol 940 & $0.7 \% \mathrm{w} / \mathrm{w}$ & 72 \\
\hline Capsaicin and capsicum tincture & Carbopol 940 & $1 \% \mathrm{w} / \mathrm{w}$ & 105 \\
\hline Ligustrazine phosphate & Carbopol 940 & $1 \% w / w$ & 106 \\
\hline Repaglinide & Carbopol 940 & $1.5 \% \mathrm{w} / \mathrm{w}$ & 53 \\
\hline Valsartan & Carbopol 940 & $1 \% w / w$ & 107 \\
\hline Erythromycin & Carbopol 974 & $1 \% \mathrm{w} / \mathrm{w}$ & 108 \\
\hline Erythromycin & Carbopol 974 & NM & 109 \\
\hline Cetirizine & Carbopol $980 \mathrm{NF}$ & $1.25 \%$ & 98 \\
\hline Griseofulvin & Carbopol $980 \mathrm{NF}$ & $0.5 \% \mathrm{w} / \mathrm{w}$ & 110 \\
\hline 5-Fluorouracil & Carbopol ultrez & $0.8 \% \mathrm{w} / \mathrm{w}$ & 18 \\
\hline Ibuprofen & Carbopol (grade NM) & NM & 111 \\
\hline Felodipine & Hydroxypropyl cellulose & $1.5 \% \mathrm{w} / \mathrm{v}$ & 112 \\
\hline Fluconazole & Hydroxypropyl methyl cellulose K4M & $2 \% w / w$ & 113 \\
\hline Mitoxantrone & Hydroxypropyl methylcellulose RG4T & $10 \% \mathrm{w} / \mathrm{v}$ & 114 \\
\hline Salbutamol sulfate & Pluronic FI27 & $20 \% w / w$ & 39 \\
\hline Granisetron hydrochloride & Lutrol FI27 & $20 \% \mathrm{w} / \mathrm{w}$ & 115 \\
\hline Metronidazole & Sodium alginate & $8 \% w / v$ & 116 \\
\hline Cannabidiol & NM & NM & 117 \\
\hline Diclofenac & NM & NM & 8 \\
\hline
\end{tabular}

Abbreviation: NM, not mentioned.

\section{Ethosomal patches}

The preparation and evaluation of ethosomal patches are more complicated than for ethosomal gels, as molds are required for their preparation. Based on a literature search, only seven research articles had reported ethosomal patch formulations for several drugs, ie, testosterone, ${ }^{6}$ artesunate and febrifugine, ${ }^{27}$ ligustrazine, ${ }^{34,118}$ valsartan, ${ }^{37}$ tizanidine hydrochloride, ${ }^{119}$ and insulin. ${ }^{120}$ Different polymers were used to prepare the ethosomal patches, including polyvinylpyrrolidone/vinyl acetate, acrylic resin, and hydroxypropyl methylcellulose E15. Triethyl citrate was added to the formulation as a plasticizer.
Touitou et $a l^{6}$ compared the in vitro and in vivo transdermal delivery properties from ethosomal patches and the nonethosomal patches of testosterone marketed as Testoderm; both patches had the same dimensions and drug contents. In vitro studies were done using Franz diffusion cells and rabbit pinna skin taken from the ear. The results showed that 24 hours after application, the amount of testosterone permeated from the ethosomal patches was 30 times higher $(848.16 \pm 158.38 \mu \mathrm{g})$ than the Testoderm patches $(27.79 \pm 16.23 \mu \mathrm{g})$, while drug deposition in the skin was seven times higher from the ethosomal patch than the Testoderm patch. 
The in vivo studies of testosterone ethosomal patches and Testoderm were conducted in two stages using rabbits. In the first stage, the serum concentrations of the drug were measured at different time intervals up to 24 hours, after a single application of both patches in the central area of the rabbits' inner ears. In the second stage, the total serum concentrations of the drug were measured after multiple applications of both patches for a period of 5 days (a new patch was applied every 24 hours). The results of the first stage showed that there was no significant difference in serum drug concentration between the control and treated groups. However, in the second stage, the area under the concentration-time curve of the groups treated with ethosomal patches was significantly higher (125\%) than the groups treated with Testoderm. ${ }^{6}$

Ethosomal patches have some advantages compared to ethosomal gels and creams because they offer the application of ethosomes under occlusive conditions, and hence more permeation is expected. Godin and Touitou studied the in vitro permeation behavior of bacitracin ethosomes using human cadaver skin under occlusive and nonocclusive applications. They found that there was no significant difference in drug permeation from ethosomes under either application method. It was concluded that the occlusion had almost no effect on the permeation behavior of the drugs from ethosomes. ${ }^{121}$ Similar findings related to this subject suggested that ethosomes are able to enhance the dermal delivery of drugs under occlusive and nonocclusive conditions. . $^{6,13,122}$

\section{Ethosomal creams}

There have only been two studies reporting the formulation of ethosomal creams. Both of these involved the incorporation of Curcuma longa extract-loaded ethosomal systems in a cream base as a photoprotective and antiwrinkle agent. ${ }^{79,123}$ In both studies, C. longa extract-loaded ethosomal creams were applied to human volunteers and showed promising results as either a photoprotective ${ }^{79}$ or an antiwrinkle agent. ${ }^{123}$

Based on all the aforementioned studies, the incorporation of ethosomal systems in suitable vehicles such as gels, patches, and creams improves skin permeation of the drug/ agent from the ethosomal systems. Among the vehicles discussed, gels are the most suitable vehicle for the incorporation of ethosomal systems, while ethosomal creams may be preferred for cosmetic preparations.

\section{Mechanisms of ethosomal system skin permeation}

Ethanol and phospholipids are reported to act synergistically to enhance the skin permeation of drugs in ethosomal formulations. Ethanol fluidizes the lipid bilayers of the ethosomal vesicles and the stratum corneum simultaneously, changing the arrangement and decreasing the density of skin lipids. Therefore, the highly malleable and soft vesicles of an ethosomal system will penetrate the altered structure of the stratum corneum and create a pathway through the skin. The release of the therapeutic agent occurs by the fusion of these vesicles into cell membranes in the deeper layers of the skin. ${ }^{6,124-128}$

It is suggested that transethosomes have superior skin-permeation properties over classical ethosomes. This is because transethosomes contain both ethanol and the edge activator or the penetration enhancer, which both act together to increase vesicular malleability and skin-lipid perturbation. ${ }^{19,30}$ However, the detailed mechanisms of ethosomal system skin penetration are still not fully understood. A proposed mechanism is illustrated in Figure 5.

\section{In vivo studies}

Highly diverse in vivo studies and models have been carried out by many researchers using humans, rabbits, rats, mice, and guinea pigs for the evaluation of ethosomal systems involving skin permeation, pharmacokinetics, pharmacodynamics, safety, and skin irritation studies.

The ability of ethosomal systems to penetrate intact skin, delivering molecules with diverse physicochemical properties in therapeutic amounts to the blood circulation, has been reported by several in vivo studies. For instance, Ahad et $\mathrm{al}^{37,107}$ studied the pharmacokinetic and pharmacodynamic effects of a valsartan-loaded ethosomal system in albino Wistar rats. The bioavailability of transdermal ethosomal valsartan was significantly higher (3.03 times) than the oral valsartan suspension; the area under the concentration-time profile curve from time 0 to $\infty$ for the transdermal ethosomal formulation was $177,298.82 \pm 665.01 \mathrm{ng} / \mathrm{mL} / \mathrm{h}$, while for the oral suspension it was $55,554.54 \pm 774.01 \mathrm{ng} / \mathrm{mL} / \mathrm{h}$. The dose of valsartan used in both routes was $3.6 \mathrm{mg} / \mathrm{kg}$. The reported maximum drug concentration $\left(C_{\max }\right)$ and the time taken to reach maximum concentration $\left(T_{\max }\right)$ values for the oral administration were $13,100 \pm 101.12 \mathrm{ng} / \mathrm{mL}$ and $1 \pm 0.01$ hours, respectively. The $C_{\max }$ and $T_{\max }$ values for the transdermal route were $7,944 \pm 134.32 \mathrm{ng} / \mathrm{mL}$ and $5.0 \pm 0.83$ hours, respectively. ${ }^{37}$ Ethosomal valsartan was shown to effectively reduce blood pressure by $34.11 \%$ for 48 hours in hypertensive rats. ${ }^{107}$

In vivo safety studies on humans and animals have shown that classical ethosomes are highly safe with excellent skin tolerability. ${ }^{44,64,129}$ Further in vivo safety studies are much required to evaluate the short- and long-term effects 

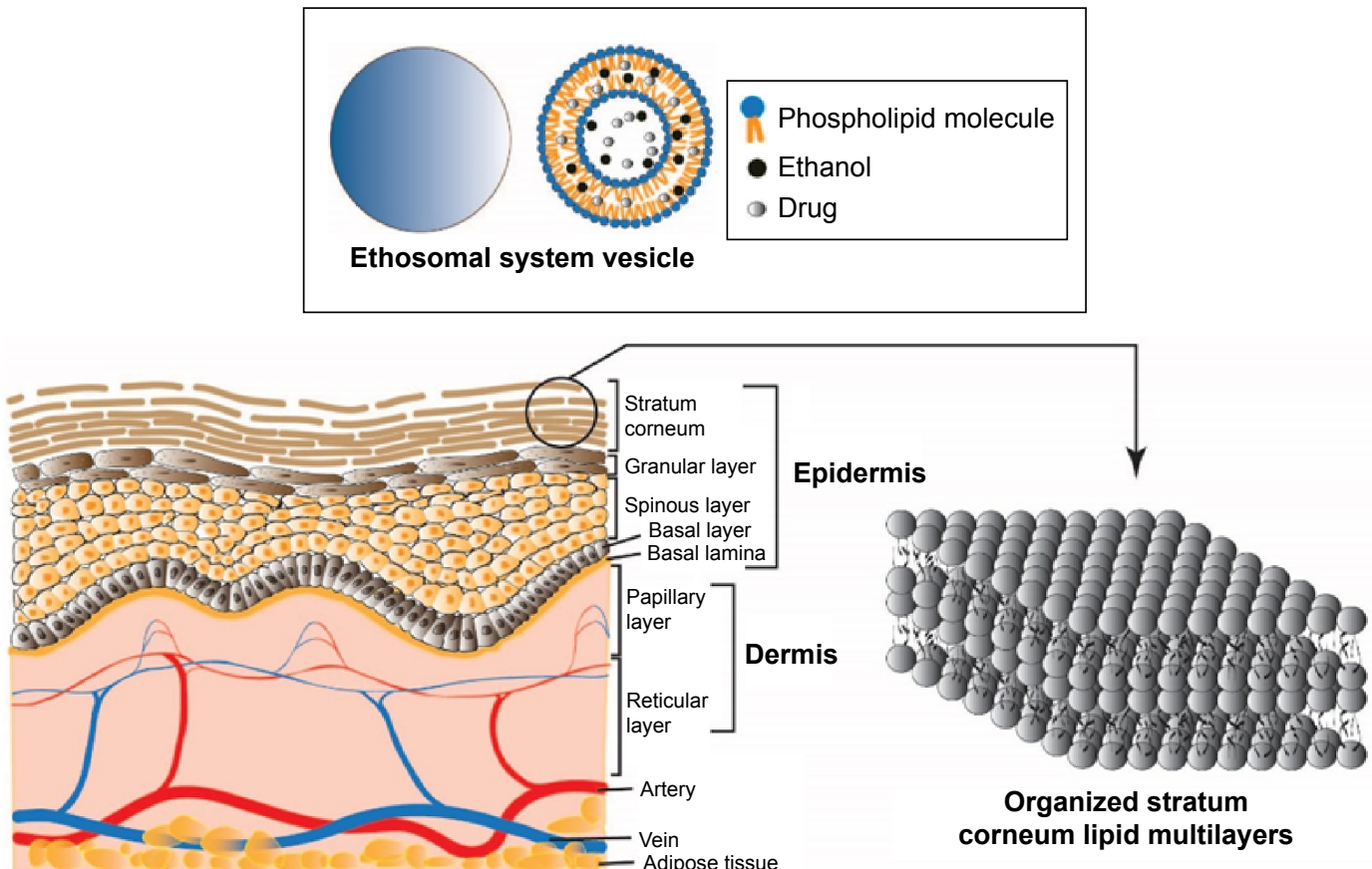

A

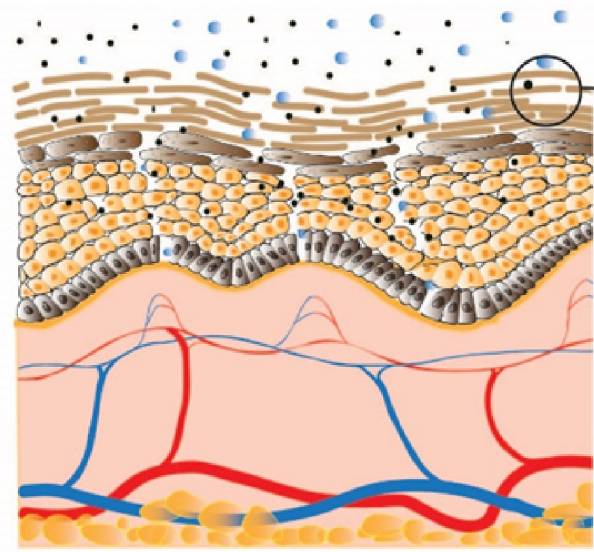

B
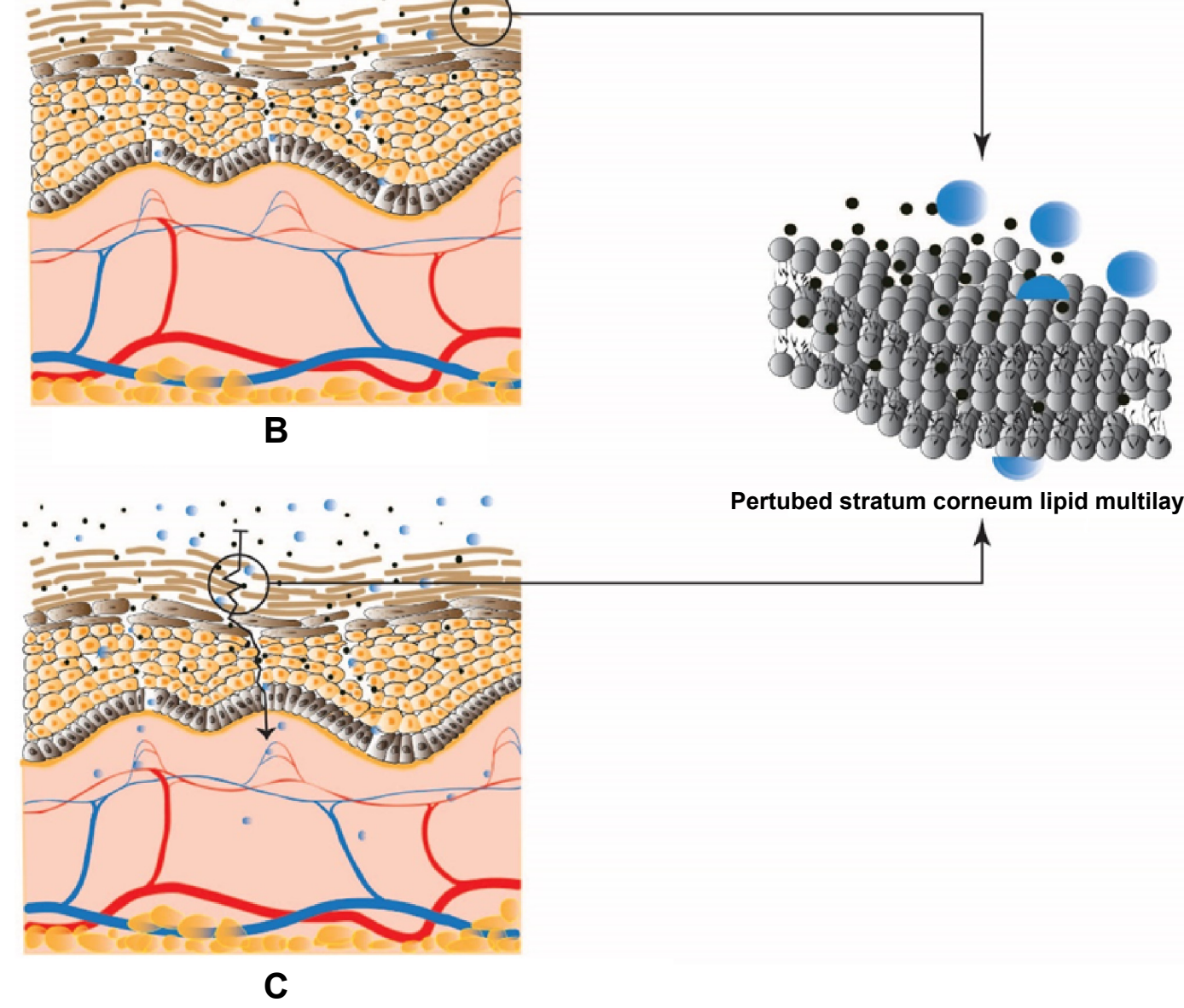

Figure 5 Proposed mechanism for permeation of molecules from ethosomal system through the skin.

Notes: (A) Normal skin; (B) Skin-lipid perturbation by ethanol effects; (C) Penetration of the soft malleable ethosomal system vesicles. 
of repeated application of these nanocarriers on the skin, particularly for the other two classes of ethosomal systems (binary ethosomes and transethosomes), which contain penetration enhancers and/or edge activators in their formulation and thus may increase the possibility of developing adverse skin reactions, such as irritations or erythema. All the in vivo studies conducted on the ethosomal systems since their invention and a summary of results are shown in Table 5. ${ }^{130-134}$

\section{Clinical trials}

Based on a literature searches, only three clinical trials have been conducted on ethosomal systems in human volunteers (Table 6). Horwitz et al carried out a pilot, double-blind, randomized clinical study to compare the efficacy of an ethosomal acyclovir preparation and commercially available acyclovir cream $\left(\right.$ Zovirax $\left.^{\circledR}\right)$ in treating recurrent herpes labialis in 40 human volunteers. The results revealed that the ethosomal acyclovir preparation performed better than Zovirax cream and showed significant improvement in all the evaluated clinical parameters, such as the time of crust formation and disappearance and pain parameters. ${ }^{135}$ The efficacy of ethosomal gel of clindamycin phosphate and salicylic acid was evaluated in a pilot clinical trial of 40 acne patients treated with the gel twice daily for 8 weeks. Volunteers treated with ethosomal gel showed considerable improvement in acne condition, with a decreased number of comedones, pustules, and total number of lesions compared to placebo. ${ }^{136}$ Ethosomal preparation of prostaglandin $\mathrm{E}_{1}$ was evaluated in a pilot clinical study in patients with erectile dysfunction. It was observed that 12 of 15 tested patients had improved peak systolic velocity and penile rigidity. Erection duration was $10-60$ minutes. ${ }^{125}$ There was no reported

Table 5 Summary of the in vivo studies

\begin{tabular}{|c|c|c|c|c|c|c|}
\hline Drug/agent & $\begin{array}{l}\text { Subjects/ } \\
\text { species }\end{array}$ & Aim & Model/method & Main results & DF & Reference(s) \\
\hline $\begin{array}{l}\text { 5-Aminolevulinic } \\
\text { acid }\end{array}$ & Nude mice & Skin penetration & $\begin{array}{l}\text { Measurement of } \\
\text { protoporphyrin IX (PpIX) } \\
\text { by CLSM }\end{array}$ & $\begin{array}{l}\text { Penetration ability of } \\
\text { ethosomal systems was } \\
\text { greater than that of } \\
\text { liposomes }\end{array}$ & Susp & 23 \\
\hline $\begin{array}{l}\text { 5-Aminolevulinic } \\
\text { acid }\end{array}$ & Nude mice & Skin-penetration behavior & $\begin{array}{l}\text { Hyperproliferative skin } \\
\text { murine model/the tape- } \\
\text { stripping technique }\end{array}$ & $\begin{array}{l}\text { Significant improvement } \\
\text { in the formation of PpIX } \\
\text { in both normal and } \\
\text { hyperproliferative skin }\end{array}$ & Susp & 58 \\
\hline 5-Fluorouracil & Nude mice & $\begin{array}{l}\text { Evaluation of the } \\
\text { antitumor effect }\end{array}$ & $\begin{array}{l}\text { Two skin cancer models: } \\
\text { I. Intradermal (ID) injection } \\
\text { of TE.354.T cells } \\
\text { 2. ID injection of ES2 cells }\end{array}$ & $\begin{array}{l}\text { Significant repression of } \\
\text { tumor-development rate } \\
\text { in both models compared } \\
\text { to the commercial } \\
\text { product }\end{array}$ & Gel & 18 \\
\hline 5-Fluorouracil & $\begin{array}{l}\text { Albino rats, } \\
\text { rabbits }\end{array}$ & $\begin{array}{l}\text { Vesicle-skin interaction } \\
\text { and drug-localization index }\end{array}$ & $\begin{array}{l}\text { Fluorescence microscopy, } \\
\text { CLSM }\end{array}$ & $\begin{array}{l}\text { Ethosomal gel showed } \\
\text { five- and tenfold deeper } \\
\text { skin penetration than } \\
\text { the lipogel and marker } \\
\text { solutions, respectively }\end{array}$ & Gel & 32 \\
\hline 5-Fluorouracil & $\begin{array}{l}\text { New Zealand } \\
\text { White rabbits }\end{array}$ & $\begin{array}{l}\text { Evaluation of } \\
\text { laryngotracheal stenosis } \\
\text { treatment }\end{array}$ & Airway-stenosis rabbit model & $\begin{array}{l}\text { Ethosomal system resulted } \\
\text { in less stenosis than the } \\
\text { 5-fluorouracil solution } \\
\text { alone }\end{array}$ & Susp & 93 \\
\hline $\begin{array}{l}\text { Ammonium } \\
\text { glycyrrhizinate }\end{array}$ & Humans & $\begin{array}{l}\text { Permeation, toxicity, and } \\
\text { anti-inflammatory activity }\end{array}$ & Model of skin erythema & $\begin{array}{l}\text { The ethosomal system } \\
\text { showed very good skin } \\
\text { tolerability, even when } \\
\text { applied for a long period } \\
\text { (48 hours) }\end{array}$ & Susp & 64 \\
\hline Apigenin & $\begin{array}{l}\text { SD rats }+ \\
\text { Kunming mice }\end{array}$ & $\begin{array}{l}\text { Skin deposition, } \\
\text { antiultraviolet effects }\end{array}$ & $\begin{array}{l}\text { Ultraviolet B-induced skin } \\
\text { inflammation }\end{array}$ & $\begin{array}{l}\text { Ethosomes showed } \\
\text { superior skin targeting in } \\
\text { reducing COX-2 levels }\end{array}$ & Susp & 16 \\
\hline Bacitracin & SD rats & $\begin{array}{l}\text { Mechanisms of skin } \\
\text { permeation }\end{array}$ & CLSM & $\begin{array}{l}\text { The antibiotic delivered } \\
\text { from ethosomes entered } \\
\text { the skin between the } \\
\text { corneocytes through the } \\
\text { intercellular lipid domain }\end{array}$ & Susp & $|2|$ \\
\hline
\end{tabular}


Table 5 (Continued)

\begin{tabular}{|c|c|c|c|c|c|c|}
\hline Drug/agent & $\begin{array}{l}\text { Subjects/ } \\
\text { species }\end{array}$ & Aim & Model/method & Main results & DF & Reference(s) \\
\hline Benzocaine & Albino rabbits & Anesthetic activity & Conjunctival reflex test & $\begin{array}{l}\text { The efficacy of ethosomal } \\
\text { benzocaine was } \\
\text { significantly improved in } \\
\text { comparison to benzocaine } \\
\text { solution }\end{array}$ & Gel & 66 \\
\hline Buspirone & $\begin{array}{l}\text { Wistar rats, } \\
\text { SD rats }\end{array}$ & $\begin{array}{l}\text { Pharmacokinetics, } \\
\text { menopause syndromes }\end{array}$ & Ovariectomized rats & $\begin{array}{l}\text { The drug was present } \\
\text { in plasma for } 12 \text { hours, } \\
\text { reaching } C_{\max } \text { after } \\
2 \text { hours. Observed } \\
\text { temperature alleviation } \\
\left(1.6^{\circ} \mathrm{C} \pm 0.7^{\circ} \mathrm{C}\right) \text { to normal } \\
\text { values after ( } 3 \text { hours) of } \\
\text { administration }\end{array}$ & Gel & 72 \\
\hline Cannabidiol & ICR mice & Anti-inflammatory effects & $\begin{array}{l}\text { Carrageenan-induced } \\
\text { inflammation }\end{array}$ & $\begin{array}{l}\text { Significant accumulation } \\
\text { of the drug in the skin and } \\
\text { in the underlying muscle. } \\
\text { Prevented inflammation } \\
\text { and edema }\end{array}$ & Gel & 117 \\
\hline Cetirizine & $\begin{array}{l}\text { BALB/c-strain } \\
\text { mice }\end{array}$ & Atopic dermatitis & $\begin{array}{l}\text { Oxazolone-induced atopic } \\
\text { dermatitis }\end{array}$ & $\begin{array}{l}\text { Enhanced therapeutic } \\
\text { performance of the } \\
\text { ethosomal system }\end{array}$ & Gel & 98 \\
\hline $\begin{array}{l}\text { Combination of } \\
\text { artesunate and } \\
\text { febrifugine }\end{array}$ & Kunming mice & Antimalarial effects & $\begin{array}{l}\text { Animals infected with } \\
\text { Plasmodium berghei }\end{array}$ & $\begin{array}{l}\text { Ethosomal cataplasm } \\
\text { showed better antimalarial } \\
\text { activity }\end{array}$ & Patch & 27 \\
\hline $\begin{array}{l}\text { Contact } \\
\text { allergens: PD, } \\
\mathrm{DCB} \text {, and } \\
\text { isoeugenol }\end{array}$ & $\mathrm{CBA} / \mathrm{Ca}$ mice & Sensitization studies & $\begin{array}{l}\text { Mouse local lymph node } \\
\text { assay }\end{array}$ & $\begin{array}{l}\text { Ethosomes were able to } \\
\text { enhance the sensitizing } \\
\text { capacity of the contact } \\
\text { allergens }\end{array}$ & Susp & 62 \\
\hline $\begin{array}{l}\text { Contact } \\
\text { allergens } \\
\text { (isoeugenol and } \\
\text { DCB) }\end{array}$ & $\mathrm{CBA} / \mathrm{Ca}$ mice & Sensitization studies & $\begin{array}{l}\text { Mouse local lymph node } \\
\text { assay }\end{array}$ & $\begin{array}{l}\text { Increased sensitizing } \\
\text { potency compared with } \\
\text { the allergens in solution }\end{array}$ & Susp & 130 \\
\hline $\begin{array}{l}\text { Curcuma longa } \\
\text { extract }\end{array}$ & Humans & Photoprotective effects & $\begin{array}{l}\text { Measuring skin hydration } \\
\text { (Cutometer) and sebum } \\
\text { content (Sebumeter) }\end{array}$ & $\begin{array}{l}\text { Improvement in skin } \\
\text { properties such as skin } \\
\text { hydration and sebum } \\
\text { content }\end{array}$ & Cream & 79 \\
\hline C. longa extract & Humans & Antiwrinkle effects & Cutometer & $\begin{array}{l}\text { The ethosomal cream } \\
\text { delivered the antiwrinkle } \\
\text { agent to the skin efficiently }\end{array}$ & Cream & 123 \\
\hline Curcumin & SD rats & Anti-inflammatory effects & $\begin{array}{l}\text { Carrageenan-induced paw } \\
\text { edema }\end{array}$ & $\begin{array}{l}\text { PG liposomes showed } \\
\text { the highest and longest } \\
\text { inhibition of the } \\
\text { development of paw } \\
\text { edema, followed by } \\
\text { ethosomes and traditional } \\
\text { liposomes }\end{array}$ & Susp & 70 \\
\hline Diclofenac & SD rats & Anti-inflammatory effects & $\begin{array}{l}\text { Carrageenan-induced paw } \\
\text { edema }\end{array}$ & $\begin{array}{l}\text { Significant inhibition } \\
\text { of paw edema with } \\
\text { ethosomal gel in } \\
\text { comparison to liposomal } \\
\text { and plain gels }\end{array}$ & Gel & 8 \\
\hline DNA & $\begin{array}{l}\text { CDI nude } \\
\text { mice }\end{array}$ & Gene delivery & CLSM & $\begin{array}{l}\text { Good ethosomal gene } \\
\text { delivery and expression in } \\
\text { skin cells }\end{array}$ & Susp & 120 \\
\hline Erythromycin & ICR mice & Antibacterial activities & $\begin{array}{l}\text { Staphylococcus aureus- } \\
\text { infected mouse skin }\end{array}$ & $\begin{array}{l}\text { Therapy with ethosomal } \\
\text { erythromycin was as } \\
\text { effective as systemically } \\
\text { administered drug }\end{array}$ & Gel & 109 \\
\hline
\end{tabular}


Table 5 (Continued)

\begin{tabular}{|c|c|c|c|c|c|c|}
\hline Drug/agent & $\begin{array}{l}\text { Subjects/ } \\
\text { species }\end{array}$ & Aim & Model/method & Main results & DF & Reference(s) \\
\hline Erythromycin & ICR mice & Antibacterial efficiency & S. aureus-infected mice skin & $\begin{array}{l}\text { Ethosomal system } \\
\text { inhibited of the infection } \\
\text { and stopped its } \\
\text { development }\end{array}$ & Gel & 108 \\
\hline Felodipine & $\begin{array}{l}\text { Wistar albino } \\
\text { rats }\end{array}$ & $\begin{array}{l}\text { Drug release through the } \\
\text { skin }\end{array}$ & $\begin{array}{l}\text { Measuring drug plasma } \\
\text { concentration }\end{array}$ & $\begin{array}{l}\text { Enhanced transdermal } \\
\text { delivery. Improved drug } \\
\text { bioavailability }\end{array}$ & Gel & 112 \\
\hline $\begin{array}{l}\text { Fraxinus } \\
\text { angustifolia } \\
\text { leaf and bark } \\
\text { extracts }\end{array}$ & CDI mice & $\begin{array}{l}\text { Antioxidant, anti- } \\
\text { inflammatory, and wound- } \\
\text { healing effects }\end{array}$ & $\begin{array}{l}\text { I2-O-Tetradecanoylphorbol- } \\
\text { I3-acetate-induced skin } \\
\text { inflammation and ulceration }\end{array}$ & $\begin{array}{l}\text { Highest antioxidant and } \\
\text { anti-inflammatory effects } \\
\text { were obtained from } \\
\text { ethylene glycol containing } \\
\text { vesicles rather than } \\
\text { ethosomes and transcutol } \\
\text { containing vesicles }\end{array}$ & Susp & $|3|$ \\
\hline Griseofulvin & Guinea pigs & $\begin{array}{l}\text { Evaluation of antifungal } \\
\text { activity }\end{array}$ & $\begin{array}{l}\text { Guinea pig model for } \\
\text { dermatophytosis }\end{array}$ & $\begin{array}{l}\text { Complete cure of the } \\
\text { fungal infection in } 8 \text { days } \\
\text { for ethosomes and } \\
14 \text { days for liposomes }\end{array}$ & Gel & 110 \\
\hline Hyaluronic acid & $\begin{array}{l}\mathrm{SKHI}{ }^{H R} \text { strain } \\
\text { hairless mice }\end{array}$ & Skin penetration & Fluorescence spectroscopy & $\begin{array}{l}\text { A fivefold enhancement } \\
\text { in penetration was found } \\
\text { compared to PBS control }\end{array}$ & Susp & 21 \\
\hline Ibuprofen & $\begin{array}{l}\text { Mice, Wistar } \\
\text { rats }\end{array}$ & $\begin{array}{l}\text { Pharmacokinetics, } \\
\text { analgesic and antipyretic } \\
\text { effects }\end{array}$ & $\begin{array}{l}\text { Tail-flick nociception mice, } \\
\text { brewer's yeast-induced } \\
\text { fever rat }\end{array}$ & $\begin{array}{l}\text { The analgesic effect of } \\
\text { ethosomal ibuprofen gel } \\
\text { was comparable to oral } \\
\text { treatment }\end{array}$ & Gel & III \\
\hline Insulin & SD rats & $\begin{array}{l}\text { Blood glucose levels } \\
\text { lowering effectiveness }\end{array}$ & Diabetic rats & $\begin{array}{l}\text { Up to } 60 \% \text { decrease in } \\
\text { blood glucose levels }\end{array}$ & Patch & 120 \\
\hline Imiquimod & SD rats & Skin deposition & $\begin{array}{l}\text { Fluorescence } \\
\text { spectrophotometer }\end{array}$ & $\begin{array}{l}\text { Transethosomes showed } \\
\text { significantly higher skin } \\
\text { deposition of the drug } \\
\text { than the marketed } \\
\text { product Aldara }^{\circledR}\end{array}$ & Susp & 29 \\
\hline $\begin{array}{l}\text { Isoeugenol and } \\
\text { MDG }\end{array}$ & Humans & $\begin{array}{l}\text { Evaluation of the allergens } \\
\text { induced responses }\end{array}$ & Patch-test conditions & $\begin{array}{l}\text { Significantly enhanced } \\
\text { patch-test reactions in } \\
\text { comparison with the } \\
\text { allergen hydroethanolic } \\
\text { solution }\end{array}$ & Susp & 61 \\
\hline Ketoconazole & Wistar rats & Antifungal activity & $\begin{array}{l}\text { Rats with skin, induced } \\
\text { fungal infection }\end{array}$ & $\begin{array}{l}\text { Transethosomes enhanced } \\
\text { the antifungal activity in a } \\
\text { shorter duration of time } \\
\text { than other vesicles }\end{array}$ & Susp & 26 \\
\hline Lidocaine & Guinea pigs & Anesthetic activity & Pinprick tests & $\begin{array}{l}\text { Shorter onset and } \\
\text { longer duration than } \\
\text { the liposomes or } \\
\text { hydroethanolic solution }\end{array}$ & Susp & 59 \\
\hline Ligustrazine & SD rats & Pharmacokinetics & $\begin{array}{l}\text { Determination of plasma } \\
\text { drug concentration by HPLC }\end{array}$ & $\begin{array}{l}\text { Ethosomal system- } \\
\text { enhanced drug absorption } \\
\text { and bioavailability }\end{array}$ & Patch & 34 \\
\hline Ligustrazine & SD rats & $\begin{array}{l}\text { Pharmacokinetics, } \\
\text { antimyocardial ischemic } \\
\text { effects }\end{array}$ & $\begin{array}{l}\text { Rat model of acute } \\
\text { myocardial ischemia }\end{array}$ & $\begin{array}{l}\text { Highest AUC was } \\
\text { achieved by the ethosomal } \\
\text { patch }\end{array}$ & Patch & 118 \\
\hline $\begin{array}{l}\text { Ligustrazine } \\
\text { phosphate }\end{array}$ & SD rats & $\begin{array}{l}\text { Anti-Alzheimer's disease } \\
\text { effects }\end{array}$ & $\begin{array}{l}\text { Scopolamine-induced } \\
\text { amnesia model in rats }\end{array}$ & $\begin{array}{l}\text { Ethosomal system is } \\
\text { a potential alternative } \\
\text { therapy for Alzheimer's } \\
\text { disease }\end{array}$ & Gel & 106 \\
\hline
\end{tabular}


Table 5 (Continued)

\begin{tabular}{|c|c|c|c|c|c|c|}
\hline Drug/agent & $\begin{array}{l}\text { Subjects/ } \\
\text { species }\end{array}$ & Aim & Model/method & Main results & DF & Reference(s) \\
\hline $\begin{array}{l}\text { Low-molecular- } \\
\text { weight heparin } \\
(\mathrm{LMWH})\end{array}$ & Hairless mice & Pharmacokinetics & $\begin{array}{l}\text { Measurement of anti-factor } \\
\text { Xa activity as an indicator } \\
\text { of LMWH bioactivity using } \\
\text { Coates }^{\circledR} \text { colorimetric plasma } \\
\text { assay }\end{array}$ & $\begin{array}{l}\text { Better skin permeation } \\
\text { and bioavailability of } \\
\text { LMWH achieved with } \\
\text { flexible liposomes than } \\
\text { ethosomes }\end{array}$ & Susp & 94 \\
\hline $\begin{array}{l}\text { Lycopene } \\
\text { extract from } \\
\text { tomato }\end{array}$ & NMRI mice & $\begin{array}{l}\text { Antioxidant and anti- } \\
\text { inflammatory activities }\end{array}$ & $\begin{array}{l}\text { Anthralin-induced ear edema } \\
\text { animal model }\end{array}$ & $\begin{array}{l}\text { Ethosomes were able } \\
\text { to decrease the level of } \\
\text { anthralin-induced ear } \\
\text { swelling in a way that was } \\
\text { highly comparable to the } \\
\text { positive control }\end{array}$ & Susp & 54 \\
\hline Matrine & SD rats & Anti-inflammatory activity & $\begin{array}{l}\text { Reflection } \\
\text { spectrophotometer }\end{array}$ & $\begin{array}{l}\text { Improved anti- } \\
\text { inflammatory activity }\end{array}$ & Susp & 38 \\
\hline Melatonin & Albino rabbits & Skin irritation studies & Scoring degree of erythema & $\begin{array}{l}\text { Good skin tolerability of } \\
\text { the ethosomal system }\end{array}$ & Susp & 44 \\
\hline Meloxicam & $\begin{array}{l}\text { Albino Wistar } \\
\text { rats }\end{array}$ & Anti-inflammatory activity & $\begin{array}{l}\text { Carrageenan-induced rat } \\
\text { paw-edema model }\end{array}$ & $\begin{array}{l}\text { Significantly higher } \\
\text { percentage inhibition of } \\
\text { edema in comparison with } \\
\text { the oral route }\end{array}$ & Gel & 101 \\
\hline Methoxsalen & Wistar rats & $\begin{array}{l}\text { Skin-photosensitization } \\
\text { studies }\end{array}$ & UV-light exposure & $\begin{array}{l}\text { Ethosomal methoxsalen } \\
\text { showed profoundly less } \\
\text { phototoxicity on the skin }\end{array}$ & Gel & 103 \\
\hline Mitoxantrone & $\begin{array}{l}\text { BALB/c nude } \\
\text { mice, Wistar } \\
\text { rats }\end{array}$ & Antimelanoma & Melanoma-bearing mice & $\begin{array}{l}\text { Ethosomal mitoxantrone } \\
\text { showed higher } \\
\text { antimelanoma effect than } \\
\text { the same drug solution }\end{array}$ & Gel & 114 \\
\hline $\begin{array}{l}\text { Mouse } \\
\text { epidermal } \\
\text { growth factor } \\
\text { (mEGF) }\end{array}$ & C57BL/6 mice & $\begin{array}{l}\text { Penetration mechanisms } \\
\text { and biological effects }\end{array}$ & $\begin{array}{l}\text { Penetration pathways and } \\
\text { depth were observed by } \\
\text { CLSM }\end{array}$ & $\begin{array}{l}\text { Penetration was mainly } \\
\text { through the pilosebaceous } \\
\text { unit and partly through } \\
\text { the intercellular domain }\end{array}$ & Susp & 132 \\
\hline Psoralen & SD rats & $\begin{array}{l}\text { Evaluation of drug release } \\
\text { in the skin }\end{array}$ & Using skin microdialysis & $\begin{array}{l}\text { Peak concentration } \\
\text { and AUC of ethosomal } \\
\text { psoralen were } 3.37 \\
\text { and } 2.34 \text { times higher } \\
\text { than psoralen tincture, } \\
\text { respectively }\end{array}$ & Susp & 55 \\
\hline Psoralen & SD rats & Skin deposition studies & $\begin{array}{l}\text { Extracted drug determined } \\
\text { by HPLC }\end{array}$ & $\begin{array}{l}\text { Ethosomes showed } \\
\text { enhanced psoralen } \\
\text { permeability and targeting } \\
\text { deep skin via intercellular } \\
\text { and intracellular transport } \\
\text { pathways }\end{array}$ & Susp & 133 \\
\hline Psoralen & Rats & $\begin{array}{l}\text { Investigating } \\
\text { biocompatibility of the } \\
\text { vesicles with the skin }\end{array}$ & $\begin{array}{l}\text { Testing the skin using } \\
\text { inverted fluorescence } \\
\text { microscopy }\end{array}$ & $\begin{array}{l}\text { Ethosomes and liposomes } \\
\text { were found to be safe } \\
\text { following daily application } \\
\text { and for } 7 \text { days }\end{array}$ & Susp & 129 \\
\hline Repaglinide & $\begin{array}{l}\text { Albino Wistar } \\
\text { rats }\end{array}$ & Antidiabetic activity & $\begin{array}{l}\text { Alloxan solution-induced } \\
\text { diabetes model }\end{array}$ & $\begin{array}{l}\text { Prolonged antidiabetic } \\
\text { effect of the drug over a } \\
\text { significantly longer period } \\
\text { of time in comparison } \\
\text { with the equivalent oral } \\
\text { dose }\end{array}$ & Gel & 53 \\
\hline Silymarin & SD rats & $\begin{array}{l}\text { Pharmacokinetics and } \\
\text { tissue distribution of } \\
\text { orally or IV-administered } \\
\text { ethosomes }\end{array}$ & $\begin{array}{l}\text { Using liquid chromatography } \\
\text { with tandem mass } \\
\text { spectrometry (LC-MS/MS) }\end{array}$ & & Susp & 134 \\
\hline
\end{tabular}


Table 5 (Continued)

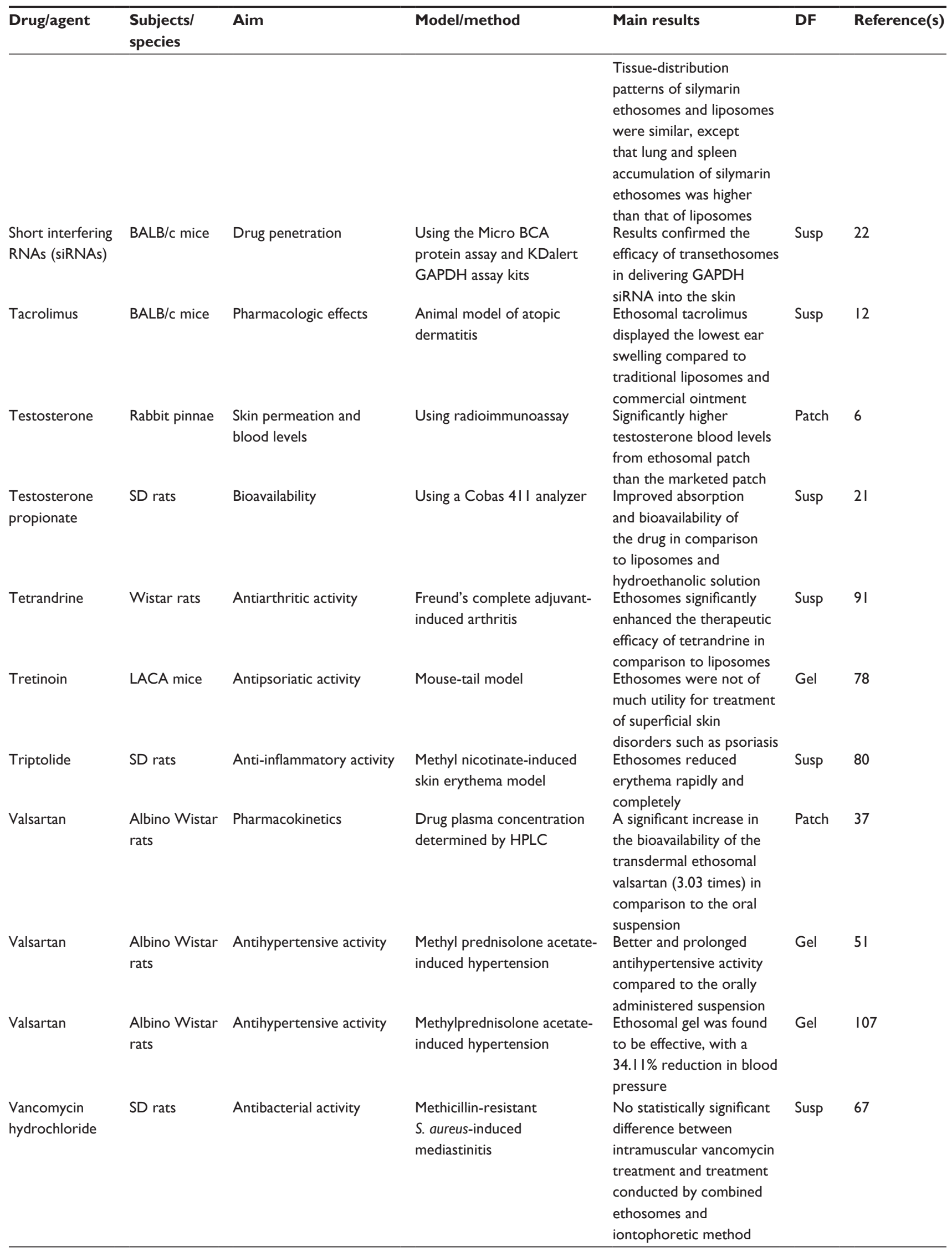


Table 5 (Continued)

\begin{tabular}{|c|c|c|c|c|c|c|}
\hline Drug/agent & $\begin{array}{l}\text { Subjects/ } \\
\text { species }\end{array}$ & Aim & Model/method & Main results & DF & Reference(s) \\
\hline Vinpocetine & SD rats & Pharmacokinetics & $\begin{array}{l}\text { Drug plasma concentration } \\
\text { determined by HPLC }\end{array}$ & $\begin{array}{l}\text { AUC and elimination } \\
\text { half-life of transdermal } \\
\text { administration were } \\
\text { significantly higher than } \\
\text { that by intragastric } \\
\text { administration }(P<0.0 \text { I) }\end{array}$ & Gel & 104 \\
\hline Voriconazole & Hairless mice & Skin deposition studies & $\begin{array}{l}\text { Extracted drug from the skin } \\
\text { determined by HPLC }\end{array}$ & $\begin{array}{l}\text { Enhanced skin deposition } \\
\text { of the drug in the } \\
\text { dermis/epidermis region } \\
\text { compared to other } \\
\text { formulations }\end{array}$ & Susp & 17 \\
\hline Zidovudine & SD rats & $\begin{array}{l}\text { Vesicle-skin interaction } \\
\text { study }\end{array}$ & $\begin{array}{l}\text { Histological studies using } \\
\text { optical microscope }\end{array}$ & $\begin{array}{l}\text { Ethosomes affected the } \\
\text { ultrastructure of the } \\
\text { stratum corneum }\end{array}$ & Susp & 45 \\
\hline
\end{tabular}

Abbreviations: AUC, area under the (plasma drug concentration-time) curve; CLSM, confocal laser-scanning microscopy; $C_{m a x}$, maximum concentration; DCB, dinitrochlorobenzene; DF, dosage form; HPLC, high-performance liquid chromatography; IV, intravenous; MDG, methyldibromoglutaronitrile; PBS, phosphate-buffered saline; PD, potassium dichromate; SD, Sprague Dawley; Susp, suspension; UV, ultraviolet.

adverse skin reactions associated with the treatment in any of the aforementioned clinical trials.

\section{Ethosomal systems for other applications}

Some have studied ethosomal systems containing iodine for computed tomography as contrast agent for imaging applications. ${ }^{137,138}$ Coelho et al used ethosomes for the entrapment of new lipophilic excited-state intramolecular proton-transfer dyes for fluorescence spectroscopy. ${ }^{139}$ In another study, a hair dye of transethosomes was developed and found to be more efficient in delivering and enhancing the adsorption of black tea extracts to the hair surface than a hydroalcoholic solution of the same extract. ${ }^{28}$

\section{Ethosomal systems for other administrations}

Ethosomal systems have also been reported for other administrations, such as oral ${ }^{134}$ and vaginal. ${ }^{116}$ Chang et al studied the ability of ethosomes and liposomes to enhance the oral bioavailability and tissue distribution of silymarin in an in vivo study. Pharmacokinetic results revealed that both vesicular systems (ie, ethosomes and liposomes) were able to improve the bioavailability of silymarin, but better results were gained from liposomes. For tissue distribution, it was found that the silymarin-loaded ethosomes had high accumulation in the lung. The authors suggested that ethosomes may have the potential to be used as a lung-targeting drug carrier for the treatment of lung diseases. ${ }^{134}$ Furthermore, the in vitro permeation of an ethosomal gel of metronidazole intended for vaginal delivery was evaluated by Mbah et al using Franz diffusion cells and regenerated cellulose semipermeable membrane. The ethosomal gel demonstrated sustained delivery of metronidazole, with a maximum flux of $143.67 \pm 2.73 \mu \mathrm{g} / \mathrm{cm}^{2} / \mathrm{h} .{ }^{116}$ However, in vivo studies are required to evaluate the suitability of ethosomal systems for this route of administration.

\section{Stability of ethosomal nanocarriers}

Stability studies in terms of vesicular structure and size distribution of ethosomal systems containing various drug entities in their initial suspension form or after their incorporation in a particular dosage form, such as gels, patches, or creams, have been conducted by many

Table 6 Summary of the clinical trials

\begin{tabular}{|c|c|c|c|c|}
\hline Drug/agent & Dosage forms/types & Volunteers, n & Clinical trial type & Reference(s) \\
\hline Acyclovir & NM & 40 & Pilot clinical trial & 135 \\
\hline $\begin{array}{l}\text { Clindamycin phosphate and } \\
\text { salicylic acid (CLSA) combination }\end{array}$ & Ethosomal gel & 40 & Pilot clinical trial & 136 \\
\hline Prostaglandin $\mathrm{E}_{\mathrm{I}}$ (PGEI) & NM & 15 & Pilot clinical trial & 125 \\
\hline
\end{tabular}

Abbreviation: NM, not mentioned. 
researchers and shown promising results. ${ }^{9,11,13,20,27,140}$ However, few studies were continued for 1 year or more. Classical ethosome suspensions of minoxidil, testosterone, ${ }^{6}$ and trihexyphenidyl $\mathrm{HCl}^{43}$ were found to be stable for 2 years, while a classical ethosome gel of erythromycin was found to be stable for $\sim 1$ year. ${ }^{108}$ A stability study of a transethosome gel of 5-fluorouracil showed that there were no changes in appearance and vesicular size after 2 months under accelerated conditions and 11 months at room temperature. ${ }^{18}$ However, more studies are much required to evaluate the stability of ethosomal systems for long-term storage, particularly when they are incorporated in dosage forms.

\section{Ethosomal system-based marketed products}

A research development company (Yissum) in the Hebrew University of Jerusalem and Professor Elka Touitou have worked together with Trima (pharmaceutical company) in the production of an ethosomal cream of acyclovir (Supravir). The preparation was used for the treatment of herpes simplex virus infections of the skin and mucous membrane. ${ }^{141}$ However, the product information is no longer available at the producing company's website. Other ethosomal systembased products reported by some authors include Nanominox, Cellutight EF, Skin Genuity, and Decorin cream. ${ }^{127,142}$ These products were produced a few years ago, but currently there is no detailed information available online about the products or their producing companies.

\section{Conclusion}

It has been almost 2 decades since the invention of ethosomes, and during this period these nanocarriers have proven their unique ability to deliver therapeutic agents of different physicochemical properties through the skin for local and systemic use. Continuous extensive research has led to the introduction of a new generation of ethosomal systems called transethosomes, which have been found to have better properties over the classical ethosomes in terms of vesicular properties and skin-permeation abilities. Transethosomes provide the highest flexibility to the formulator to change the ethosomal properties according to the required research criteria by changing the edge activators and/or penetration enhancers. The incorporation of ethosomal systems in suitable vehicles such as gels, patches, and creams represents an important step to get better skin-permeation and therapeutic results. However, more studies are required to enhance the stability of the ethosomal system. The results of the in vivo studies and clinical trials are reflecting the potential of ethosomal systems in dermal and transdermal delivery of therapeutic and cosmetic agents.

\section{Acknowledgments}

The authors would like to thank Universiti Sains Malaysia for providing a research university grant (1001/ PFarmasi/811285) to support this work. The author (Ibrahim M Abdulbaqi) gratefully acknowledges Universiti Sains Malaysia, 11800 Penang, Malaysia for the granting of a graduate assistant.

\section{Disclosure}

The authors report no conflicts of interest in this work.

\section{References}

1. Prausnitz MR, Langer R. Transdermal drug delivery. Nat Biotechnol. 2008;26(11):1261-1268.

2. Schoellhammer CM, Blankschtein D, Langer R. Skin permeabilization for transdermal drug delivery: recent advances and future prospects. Expert Opin Drug Deliv. 2014;11(3):393-407.

3. Mezei M, Gulasekharam V. Liposomes - a selective drug delivery system for the topical route of administration: I. Lotion dosage form. Life Sci. 1980;26(18):1473-1477.

4. Cevc G, Blume G. Lipid vesicles penetrate into intact skin owing to the transdermal osmotic gradients and hydration force. Biochim Biophys Acta. 1992;1104(1):226-232.

5. Touitou E. inventor and assignee. Compositions for applying active substances to or through the skin. United States patent US 5540934 A. 1996 Jul 30.

6. Touitou E, Dayan N, Bergelson L, Godin B, Eliaz M. Ethosomes — novel vesicular carriers for enhanced delivery: characterization and skin penetration properties. J Control Release. 2000;65(3):403-418.

7. Sarwa KK, Suresh PK, Rudrapal M, Verma VK. Penetration of tamoxifen citrate loaded ethosomes and liposomes across human skin: a comparative study with confocal laser scanning microscopy. Curr Drug Deliv. 2014;11(3):332-337.

8. Jain S, Patel N, Madan P, Lin S. Quality by design approach for formulation, evaluation and statistical optimization of diclofenac-loaded ethosomes via transdermal route. Pharm Dev Technol. 2015;20(4): 473-489.

9. Zhang Z, Wo Y, Zhang Y, et al. In vitro study of ethosome penetration in human skin and hypertrophic scar tissue. Nanomedicine. 2012;8(6): 1026-1033.

10. Mishra D, Mishra PK, Dabadghao S, Dubey V, Nahar M, Jain NK. Comparative evaluation of hepatitis B surface antigen-loaded elastic liposomes and ethosomes for human dendritic cell uptake and immune response. Nanomedicine. 2010;6(1):110-118.

11. Zhou Y, Wei Y, Liu H, Zhang G, Wu X. Preparation and in vitro evaluation of ethosomal total alkaloids of Sophora alopecuroides loaded by a transmembrane $\mathrm{pH}$-gradient method. AAPS PharmSciTech. 2010;11(3):1350-1358.

12. Li G, Fan Y, Fan C, et al. Tacrolimus-loaded ethosomes: physicochemical characterization and in vivo evaluation. Eur J Pharm Biopharm. 2012; 82(1):49-57.

13. Zhang JP, Wei YH, Zhou Y, Li YQ, Wu XA. Ethosomes, binary ethosomes and transfersomes of terbinafine hydrochloride: a comparative study. Arch Pharm Res. 2012;35(1):109-117.

14. Akhtar N, Pathak K. Cavamax W7 composite ethosomal gel of clotrimazole for improved topical delivery: development and comparison with ethosomal gel. AAPS PharmSciTech. 2012;13(1):344-355. 
15. Dave V, Kumar D, Lewis S, Paliwal S. Ethosome for enhanced transdermal drug delivery of aceclofenac. Int J Drug Deliv. 2010;2(1):81-92.

16. Shen LN, Zhang YT, Wang Q, Xu L, Feng NP. Enhanced in vitro and in vivo skin deposition of apigenin delivered using ethosomes. Int J Pharm. 2014;460(1-2):280-288.

17. Song CK, Balakrishnan P, Shim CK, Chung SJ, Chong S, Kim DD. A novel vesicular carrier, transethosome, for enhanced skin delivery of voriconazole: characterization and in vitro/in vivo evaluation. Colloids Surf B Biointerfaces. 2012;92:299-304.

18. Ainbinder D, Touitou E. A new approach for skin tumor treatment: from delivery system characterization to in vivo evaluation. Drug Deliv Transl Res. 2011;1(1):53-65.

19. Bragagni M, Mennini N, Maestrelli F, Cirri M, Mura P. Comparative study of liposomes, transfersomes and ethosomes as carriers for improving topical delivery of celecoxib. Drug Deliv. 2012;19(7): 354-361.

20. Meng S, Chen Z, Yang L, et al. Enhanced transdermal bioavailability of testosterone propionate via surfactant-modified ethosomes. Int J Nanomedicine. 2013;8:3051-3060.

21. Chen M, Gupta V, Anselmo AC, Muraski JA, Mitragotri S. Topical delivery of hyaluronic acid into skin using SPACE-peptide carriers. J Control Release. 2014;173:67-74.

22. Chen M, Zakrewsky M, Gupta V, et al. Topical delivery of siRNA into skin using SPACE-peptide carriers. J Control Release. 2014;179 33-41.

23. Fang YP, Tsai YH, Wu PC, Huang YB. Comparison of 5-aminolevulinic acid-encapsulated liposome versus ethosome for skin delivery for photodynamic therapy. Int J Pharm. 2008;356(1-2):144-152.

24. Limsuwan T, Amnuaikit T. Development of ethosomes containing mycophenolic acid. Procedia Chem. 2012;4:328-335.

25. Verma P, Ram A. Effect of different penetration enhancers on skin permeation of drug using ethosomal carrier systems. J Curr Pharm Res. 2011;5(1):42-44.

26. Guo F, Wang J, Ma M, Tan F, Li N. Skin targeted lipid vesicles as novel nano-carrier of ketoconazole: characterization, in vitro and in vivo evaluation. J Mater Sci Mater Med. 2015;26(4):1-13.

27. Shen S, Liu SZ, Zhang YS, et al. Compound antimalarial ethosomal cataplasm: preparation, evaluation, and mechanism of penetration enhancement. Int J Nanomedicine. 2015;10:4239-4253.

28. Yeh MI, Huang HC, Liaw JH, et al. Ethosomes in hair dye products as carriers of the major compounds of black tea extracts. Int $J$ Dermatol. 2013;52(7):868-875

29. Ma M, Wang J, Guo F, Lei M, Tan F, Li N. Development of nanovesicular systems for dermal imiquimod delivery: physicochemical characterization and in vitro/in vivo evaluation. J Mater Sci Mater Med. 2015; 26(6):1-11.

30. Ascenso A, Raposo S, Batista C, et al. Development, characterization, and skin delivery studies of related ultradeformable vesicles: transfersomes, ethosomes, and transethosomes. Int J Nanomedicine. 2015;10 5837-5851.

31. Finnin BC, Morgan TM. Transdermal penetration enhancers: Applications, limitations, and potential. J Pharm Sci. 1999;88(10):955-958.

32. Puri R, Jain S. Ethogel topical formulation for increasing the local bioavailability of 5-fluorouracil: a mechanistic study. Anticancer Drugs. 2012; 23(9):923-934.

33. López-Pinto JM, González-Rodríguez ML, Rabasco AM. Effect of cholesterol and ethanol on dermal delivery from DPPC liposomes. Int J Pharm. 2005;298(1):1-12.

34. Liu X, Liu H, Liu J, et al. Preparation of a ligustrazine ethosome patch and its evaluation in vitro and in vivo. Int J Nanomedicine. 2011;6: 241-247.

35. Patel KK, Kumar P, Thakkar HP. Formulation of niosomal gel for enhanced transdermal lopinavir delivery and its comparative evaluation with ethosomal gel. AAPS PharmSciTech. 2012;13(4):1502-1510.

36. Rakesh R, Anoop KR. Formulation and optimization of nano-sized ethosomes for enhanced transdermal delivery of cromolyn sodium. J Pharm Bioallied Sci. 2012;4(4):333-340.
37. Ahad A, Aqil M, Kohli K, Sultana Y, Mujeeb M. Enhanced transdermal delivery of an anti-hypertensive agent via nanoethosomes: statistical optimization, characterization and pharmacokinetic assessment. Int J Pharm. 2013;443(1-2):26-38.

38. Zhaowu Z, Xiaoli W, Yangde Z, Nianfeng L. Preparation of matrine ethosome, its percutaneous permeation in vitro and anti-inflammatory activity in vivo in rats. J Liposome Res. 2009;19(2):155-162.

39. Bendas ER, Tadros MI. Enhanced transdermal delivery of salbutamol sulfate via ethosomes. AAPS PharmSciTech. 2007;8(4):E107.

40. Verma P, Pathak K. Nanosized ethanolic vesicles loaded with econazole nitrate for the treatment of deep fungal infections through topical gel formulation. Nanomedicine. 2012;8(4):489-496.

41. Zhou Y, Wei YH, Zhang GQ, Wu XA. Synergistic penetration of ethosomes and lipophilic prodrug on the transdermal delivery of acyclovir. Arch Pharm Res. 2010;33(4):567-574.

42. Rao Y, Zheng F, Zhang X, Gao J, Liang W. In vitro percutaneous permeation and skin accumulation of finasteride using vesicular ethosomal carriers. AAPS PharmSciTech. 2008;9(3):860-865.

43. Dayan N, Touitou E. Carriers for skin delivery of trihexyphenidyl HCl: ethosomes vs liposomes. Biomaterials. 2000;21(18): 1879-1885.

44. Dubey V, Mishra D, Jain NK. Melatonin loaded ethanolic liposomes: physicochemical characterization and enhanced transdermal delivery. Eur J Pharm Biopharm. 2007;67(2):398-405.

45. Bhadra D, Jain NK, Umamaheshwari RB, Jain S. Ethosomes: a novel vesicular carrier for enhanced transdermal delivery of an antiHIV agent. Indian J Pharm Sci. 2004;66(1):72-81.

46. Prasanthi D, Lakshmi PK. Development of ethosomes with Taguchi robust design-based studies for transdermal delivery of alfuzosin hydrochloride. Int Curr Pharm J. 2012;1(11):370-375.

47. Prasanthi D, Lakshmi PK. Statistically optimised ethosomes for transdermal delivery of tolterodine tartrate. PakJ Pharm Sci. 2013;26(6): 1117-1122.

48. Chen M, Liu X, Fahr A. Skin penetration and deposition of carboxyfluorescein and temoporfin from different lipid vesicular systems: In vitro study with finite and infinite dosage application. Int $J$ Pharm. 2011;408(1-2):223-234.

49. Sarwa KK, Suresh PK, Debnath M, Ahmad MZ. Tamoxifen citrate loaded ethosomes for transdermal drug delivery system: preparation and characterization. Curr Drug Deliv. 2013;10(4):466-476.

50. Paolino D, Celia C, Trapasso E, Cilurzo F, Fresta M. Paclitaxel-loaded ethosomes ${ }^{\circledR}$ : potential treatment of squamous cell carcinoma, a malignant transformation of actinic keratoses. Eur J Pharm Biopharm. 2012; 81(1):102-112.

51. Bhosale SS, Avachat AM. Design and development of ethosomal transdermal drug delivery system of valsartan with preclinical assessment in Wistar albino rats. J Liposome Res. 2013;23(2): 119-125.

52. Verma DD, Fahr A. Synergistic penetration enhancement effect of ethanol and phospholipids on the topical delivery of cyclosporin A. J Control Release. 2004;97(1):55-66.

53. Bodade SS, Shaikh KS, Kamble MS, Chaudhari PD. A study on ethosomes as mode for transdermal delivery of an antidiabetic drug. Drug Deliv. 2013;20(1):40-46

54. Ascenso A, Pinho S, Eleutério C, et al. Lycopene from tomatoes: vesicular nanocarrier formulations for dermal delivery. J Agric Food Chem. 2013;61(30):7284-7293.

55. Zhang YT, Shen LN, Zhao JH, Feng NP. Evaluation of psoralen ethosomes for topical delivery in rats by using in vivo microdialysis. Int $J$ Nanomedicine. 2014;9:669-678.

56. Choi JH, Cho SH, Yun JJ, Yu YB, Cho CW. Ethosomes and transfersomes for topical delivery of ginsenoside Rh1 from red ginseng: characterization and in vitro evaluation. $J$ Nanosci Nanotechnol. 2015;15(8):5660-5662.

57. Fathi-Azarbayjani A, Ng KX, Chan YW, Chan SY. Lipid vesicles for the skin delivery of diclofenac: cerosomes vs other lipid suspensions. Adv Pharm Bull. 2015;5(1):25-33. 
58. Fang YP, Huang YB, Wu PC, Tsai YH. Topical delivery of 5-aminolevulinic acid-encapsulated ethosomes in a hyperproliferative skin animal model using the CLSM technique to evaluate the penetration behavior. Eur J Pharm Biopharm. 2009;73(3):391-398.

59. Zhu X, Li F, Peng X, Zeng K. Formulation and evaluation of lidocaine base ethosomes for transdermal delivery. Anesth Analg. 2013;117(2): 352-357.

60. Rattanapak T, Young K, Rades T, Hook S. Comparative study of liposomes, transfersomes, ethosomes and cubosomes for transcutaneous immunisation: characterisation and in vitro skin penetration. $J$ Pharm Pharmacol. 2012;64(11):1560-1569.

61. Madsen JT, Vogel S, Karlberg AT, Simonsson C, Johansen JD, Andersen KE. Ethosome formulation of contact allergens may enhance patch test reactions in patients. Contact Dermatitis. 2010;63(4):209-214.

62. Madsen JT, Vogel S, Johansen JD, Andersen KE. Encapsulating contact allergens in liposomes, ethosomes, and polycaprolactone may affect their sensitizing properties. Cutan Ocul Toxicol. 2011;30(2):116-123.

63. Caddeo C, Sales OD, Valenti D, Sauri AR, Fadda AM, Manconi M. Inhibition of skin inflammation in mice by diclofenac in vesicular carriers: liposomes, ethosomes and PEVs. Int J Pharm. 2013;443(1-2):128-136.

64. Paolino D, Lucania G, Mardente D, Alhaique F, Fresta M. Ethosomes for skin delivery of ammonium glycyrrhizinate: in vitro percutaneous permeation through human skin and in vivo anti-inflammatory activity on human volunteers. J Control Release. 2005;106(1-2):99-110.

65. Jain S, Tiwary AK, Sapra B, Jain NK. Formulation and evaluation of ethosomes for transdermal delivery of lamivudine. AAPS PharmSciTech. 2007;8(4):E111.

66. Maestrelli F, Capasso G, Gonzalez-Rodriguez ML, Rabasco AM, Ghelardini C, Mura P. Effect of preparation technique on the properties and in vivo efficacy of benzocaine-loaded ethosomes. J Liposome Res. 2009;19(4):253-260.

67. Mohammed MI, Makky AM, Teaima MH, Abdellatif MM, Hamzawy MA, Khalil MA. Transdermal delivery of vancomycin hydrochloride using combination of nano-ethosomes and iontophoresis: in vitro and in vivo study. Drug Deliv. Epub 2015 Aug 19.

68. Choi HK, Flynn GL, Amidon GL. Transdermal delivery of bioactive peptides: the effect of n-decylmethyl sulfoxide, $\mathrm{pH}$, and inhibitors on enkephalin metabolism and transport. Pharm Res. 1990;7(11): 1099-1106.

69. Marren K. Dimethyl sulfoxide: an effective penetration enhancer for topical administration of NSAIDs. Phys Sportsmed. 2011;39(3):75-82.

70. Zhao YZ, Lu CT, Zhang Y, et al. Selection of high efficient transdermal lipid vesicle for curcumin skin delivery. Int J Pharm. 2013;454(1): 302-309.

71. Hsu T, Mitragotri S. Delivery of siRNA and other macromolecules into skin and cells using a peptide enhancer. Proc Natl Acad Sci U S A. 2011; 108(38):15816-15821.

72. Shumilov M, Touitou E. Buspirone transdermal administration for menopausal syndromes, in vitro and in animal model studies. Int $J$ Pharm. 2010;387(1-2):26-33.

73. Cortesi R, Romagnoli R, Drechsler M, et al. Liposomes- and ethosomes-associated distamycins: a comparative study. J Liposome Res. 2010;20(4):277-285.

74. de la Presa P, Rueda T, del Puerto Morales M, et al. Gold nanoparticles generated in ethosome bilayers, as revealed by cryo-electron-tomography. J Phys Chem B. 2009;113(10):3051-3057.

75. Chourasia MK, Kang L, Chan SY. Nanosized ethosomes bearing ketoprofen for improved transdermal delivery. Results Pharma Sci. 2011;1(1):60-67.

76. Dubey V, Mishra D, Nahar M, Jain V, Jain NK. Enhanced transdermal delivery of an anti-HIV agent via ethanolic liposomes. Nanomedicine. 2010;6(4):590-596.

77. Cortesi R, Ravani LA, Zaid AN, et al. Ethosomes for the delivery of anti-HSV-1 molecules: preparation, characterization and in vitro activity. Pharmazie. 2010;65(10):743-749.

78. Raza K, Singh B, Lohan S, et al. Nano-lipoidal carriers of tretinoin with enhanced percutaneous absorption, photostability, biocompatibility and anti-psoriatic activity. Int J Pharm. 2013;456(1):65-72.
79. Kaur CD, Saraf S. Topical vesicular formulations of Curcuma longa extract on recuperating the ultraviolet radiation-damaged skin. $J$ Cosmet Dermatol. 2011;10(4):260-265.

80. Chen JG, Liu YF, Gao TW. Preparation and anti-inflammatory activity of triptolide ethosomes in an erythema model. J Liposome Res. 2010; 20(4):297-303.

81. Touitou E, Godin B, Dayan N, Weiss C, Piliponsky A, Levi-Schaffer F. Intracellular delivery mediated by an ethosomal carrier. Biomaterials. 2001;22(22):3053-3059.

82. Elsayed MM, Abdallah OY, Naggar VF, Khalafallah NM. Deformable liposomes and ethosomes: mechanism of enhanced skin delivery. Int J Pharm. 2006;322(1-2):60-66.

83. Navneet B, Arvind S. Preparation of novel vesicular carrier ethosomes with glimepiride and their investigation of permeability. Int J Therap Appl. 2012;2:1-10.

84. Ashoniya S, Meenakshi C. Ethosomes as vesicular carrier for enhanced transdermal delivery of ketoconazole - formulation and evaluation. J Pharm Cosmetol. 2011;1(3):1-14.

85. Park S, Lee H, Gu H. Enhanced skin delivery and characterization of rutin-loaded ethosomes. Korean J Chem Eng. 2014;31(3):485-489.

86. Maheshwari RG, Tekade RK, Sharma PA, et al. Ethosomes and ultradeformable liposomes for transdermal delivery of clotrimazole: a comparative assessment. Saudi Pharm J. 2012;20(2):161-170.

87. Mishra D, Mishra PK, Dubey V, Nahar M, Dabadghao S, Jain NK. Systemic and mucosal immune response induced by transcutaneous immunization using hepatitis B surface antigen-loaded modified liposomes. Eur J Pharm Sci. 2008;33(4-5):424-433.

88. Dubey V, Mishra D, Dutta T, Nahar M, Saraf DK, Jain NK. Dermal and transdermal delivery of an anti-psoriatic agent via ethanolic liposomes. J Control Release. 2007;123(2):148-154.

89. Nichols JW, Deamer DW. Catecholamine uptake and concentration by liposomes maintaining pH gradients. Biochim Biophys Acta. 1976; 455(1):269-271.

90. Cramer JA, Prestegard JH. NMR studies of pH-induced transport of carboxylic acids across phospholipid vesicle membranes. Biochem Biophys Res Commun. 1977;75(2):295-301.

91. Fan C, LiX, Zhou Y, et al. Enhanced topical delivery of tetrandrine by ethosomes for treatment of arthritis. Biomed Res Int. 2013;2013:161943.

92. Kumari S, Pathak K. Cavamax W7 composite psoralen ethosomal gel versus Cavamax W7 psoralen solid complex gel for topical delivery: a comparative evaluation. Int J Pharm Investig. 2013;3(4):171-182.

93. Gu J, Mao X, Li C, Ao H, Yang X. A novel therapy for laryngotracheal stenosis: treatment with ethosomes containing 5-fluorouracil. Ann Otol Rhinol Laryngol. 2015;124(7):561-566.

94. Song YK, Hyun SY, Kim HT, Kim CK, Oh JM. Transdermal delivery of low molecular weight heparin loaded in flexible liposomes with bioavailability enhancement: comparison with ethosomes. $J$ Microencapsul. 2011;28(3):151-158.

95. Chen JG, Jiang Y, Yang Z. Preparation of triptolide ethosomes. Afr J Pharm Pharmacol. 2012;6(13):998-1004.

96. Bhana R, Verma A, Jain S. Development and characterization of ethosomes bearing losartan potassium for transdermal drug delivery. Int J Pharm Pharm Sci. 2013;5(1):35-40.

97. Esposito E, Menegatti E, Cortesi R. Ethosomes and liposomes as topical vehicles for azelaic acid: a preformulation study. $J$ Cosmet Sci. 2004;55(3):253-264.

98. Goindi S, Dhatt B, Kaur A. Ethosomes-based topical delivery system of antihistaminic drug for treatment of skin allergies. J Microencapsul. 2014:31(7):716-724.

99. Elnaggar YS, El-Refaie WM, El-Massik MA, Abdallah OY. Lecithinbased nanostructured gels for skin delivery: an update on state of art and recent applications. J Control Release. 2014;180:10-24.

100. Devi M, Kumar MS, Mahadevan N. Amphotericin-B loaded vesicular systems for the treatment of topical fungal infection. Int $J$ Recent $A d v$ Pharma Res. 2011;4:37-46.

101. Ahad A, Raish M, Al-Mohizea AM, Al-Jenoobi FI, Alam MA. Enhanced anti-inflammatory activity of carbopol loaded meloxicam nanoethosomes gel. Int J Biol Macromol. 2014;67:99-104. 
102. Ainbinder D, Touitou E. Testosterone ethosomes for enhanced transdermal delivery. Drug Deliv. 2005;12(5):297-303.

103. Garg BJ, Garg NK, Beg S, Singh B, Katare OP. Nanosized ethosomesbased hydrogel formulations of methoxsalen for enhanced topical delivery against vitiligo: formulation optimization, in vitro evaluation and preclinical assessment. J Drug Target. 2016;24(3):233-246.

104. Mao YT, Hua HY, Zhang XG, et al. Ethosomes as delivery system for transdermal administration of vinpocetine. Pharmazie. 2013;68(5): 381-382.

105. Thapa B, Pepic I, Vanic Z, Basnet P, Skalko-Basnet N. Topical delivery system for phytochemicals: capsaicin and capsicum tincture. J Pharma Drug Develop. 2013;1(2):1-7.

106. Shi J, Wang Y, Luo G. Ligustrazine phosphate ethosomes for treatment of Alzheimer's disease, in vitro and in animal model studies. AAPS PharmSciTech. 2012;13(2):485-492.

107. Ahad A, Aqil M, Kohli K, Sultana Y, Mujeeb M. Nano vesicular lipid carriers of angiotensin II receptor blocker: anti-hypertensive and skin toxicity study in focus. Artif Cells Nanomed Biotechnol. Epub 2015 Feb 24.

108. Godin B, Touitou E. Erythromycin ethosomal systems: physicochemical characterization and enhanced antibacterial activity. Curr Drug Deliv. 2005;2(3):269-275

109. Godin B, Touitou E, Rubinstein E, Athamna A, Athamna M. A new approach for treatment of deep skin infections by an ethosomal antibiotic preparation: an in vivo study. J Antimicrob Chemother. 2005; 55(6):989-994.

110. Aggarwal N, Goindi S. Dermatopharmacokinetic and pharmacodynamic evaluation of ethosomes of griseofulvin designed for dermal delivery. J Nanopart Res. 2013;15(10):1-15.

111. Shumilov M, Bercovich R, Duchi S, Ainbinder D, Touitou E. Ibuprofen transdermal ethosomal gel: characterization and efficiency in animal models. J Biomed Nanotechnol. 2010;6(5):569-576.

112. Mishra AD, Khunt DM, Ghayal AH, Patel CN, Shah DR. Formulation and optimization of ethosomes for transdermal delivery of felodipine. Res J Pharm Technol. 2012;5(12):1509-1517.

113. Bhalaria MK, Naik S, Misra AN. Ethosomes: a novel delivery system for antifungal drugs in the treatment of topical fungal diseases. Indian $J$ Exp Biol. 2009;47(5):368-375.

114. Yu X, Du L, Li Y, Fu G, Jin Y. Improved anti-melanoma effect of a transdermal mitoxantrone ethosome gel. Biomed Pharmacother. 2015;73:6-11.

115. Mogal V, Puranik P. Enhanced transdermal delivery of granisetron hydrochloride via ethosomes. J Med Pharm Innov. 2013;1(1) 24-30.

116. Mbah C, Builders P, Nzekwe I, Kunle O, Adikwu M, Attama A. Formulation and in vitro evaluation of $\mathrm{pH}$-responsive ethosomes for vaginal delivery of metronidazole. J Drug Deliv Sci Technol. 2014; 24(6):565-571

117. Lodzki M, Godin B, Rakou L, Mechoulam R, Gallily R, Touitou E. Cannabidiol - transdermal delivery and anti-inflammatory effect in a murine model. J Control Release. 2003;93(3):377-387.

118. Liu X, Liu H, Zeng Z, Zhou W, Liu J, He Z. Pharmacokinetics of ligustrazine ethosome patch in rats and anti-myocardial ischemia and anti-ischemic reperfusion injury effect. Int $J$ Nanomedicine 2011;6:1391-1398.

119. Nagadevi B, Kumar KS, Venkanna P, Prabhakar D. Formulation and characterisation of tizanidine hydrochloride loaded ethosomes patch. Int J Pharm Pharm Sci. 2014;6(4):199-205.

120. Godin B, Touitou E. Ethosomes: new prospects in transdermal delivery. Crit Rev Ther Drug Carrier Syst. 2003;20(1):63-102.

121. Godin B, Touitou E. Mechanism of bacitracin permeation enhancement through the skin and cellular membranes from an ethosomal carrier. $J$ Control Release. 2004;94(2-3):365-379.

122. Elsayed MM, Abdallah OY, Naggar VF, Khalafallah NM. Lipid vesicles for skin delivery of drugs: reviewing three decades of research. Int J Pharm. 2007;332(1-2):1-16.
123. Gunjan J, Swarnlata S. Topical delivery of Curcuma longa extract loaded nanosized ethosomes to combat facial wrinkles. J Pharm Drug Deliv Res 3. 2014;3(1):1000118.

124. Touitou E, Godin B, Weiss C. Enhanced delivery of drugs into and across the skin by ethosomal carriers. Drug Dev Res. 2000;50(3-4): 406-415.

125. Ainbinder D, Paolino D, Fresta M, Touitou E. Drug delivery applications with ethosomes. J Biomed Nanotechnol. 2010;6(5):558-568.

126. Singh D, Pradhan M, Nag M, Singh MR. Vesicular system: versatile carrier for transdermal delivery of bioactives. Artif Cells Nanomed Biotechnol. 2015;43(4):282-290.

127. Mbah CC, Builders PF, Attama AA. Nanovesicular carriers as alternative drug delivery systems: ethosomes in focus. Expert Opin Drug Deliv. 2014;11(1):45-59.

128. Akhtar N. Vesicles: a recently developed novel carrier for enhanced topical drug delivery. Curr Drug Deliv. 2014;11(1):87-97.

129. Zhang YT, Shen LN, Wu ZH, Zhao JH, Feng NP. Comparison of ethosomes and liposomes for skin delivery of psoralen for psoriasis therapy. Int J Pharm. 2014;471(1-2):449-452.

130. Madsen JT, Vogel S, Karlberg AT, Simonsson C, Johansen JD, Andersen KE. Ethosome formulations of known contact allergens can increase their sensitizing capacity. Acta Derm Venereol. 2010;90(4): 374-378.

131. Moulaoui K, Caddeo C, Manca ML, et al. Identification and nanoentrapment of polyphenolic phytocomplex from Fraxinus angustifolia: in vitro and in vivo wound healing potential. Eur J Med Chem. 2015; 89:179-188.

132. Xing XJ, Yang L, You Y, et al. Study of the biological function and penetration pathways of the mouse epidermal growth factor ethosomal delivery system. Exp Dermatol. 2011;20(11):945-947.

133. Zhang YT, Shen LN, Wu ZH, Zhao JH, Feng NP. Evaluation of skin viability effect on ethosome and liposome-mediated psoralen delivery via cell uptake. J Pharm Sci. 2014;103(10):3120-3126.

134. Chang LW, Hou ML, Tsai TH. Silymarin in liposomes and ethosomes: pharmacokinetics and tissue distribution in free-moving rats by highperformance liquid chromatography-tandem mass spectrometry. J Agric Food Chem. 2014;62(48):11657-11665.

135. Horwitz E, Pisanty S, Czerninski R, Helser M, Eliav E, Touitou E. A clinical evaluation of a novel liposomal carrier for acyclovir in the topical treatment of recurrent herpes labialis. Oral Surg Oral Med Oral Pathol Oral Radiol Endod. 1999;87(6):700-705.

136. Touitou E, Godin B, Shumilov M, et al. Efficacy and tolerability of clindamycin phosphate and salicylic acid gel in the treatment of mild to moderate acne vulgaris. $J$ Eur Acad Dermatol Venereol. 2008; 22(5):629-631.

137. Shin H, Cho YM, Lee K, Lee CH, Choi BW, Kim B. Synthesis and characterization of ethosomal contrast agents containing iodine for computed tomography (CT) imaging applications. J Liposome Res. 2014;24(2):124-129.

138. Na B, Choi BW, Kim B. Size and CT density of iodine-containing ethosomal vesicles obtained by membrane extrusion: potential for use as CT contrast agents. Biotechnol J. 2013;8(11):1347-1353.

139. Coelho FL, Rodembusch FS, Campo LF. Synthesis, characterization and photophysics of new photoactive ESIPT lipophilic dyes: partition experiments with different composed liposomes. Dyes Pigm. 2014; 110:134-142.

140. Celia C, Trapasso E, Cosco D, Paolino D, Fresta M. Turbiscan lab expert analysis of the stability of ethosomes and ultradeformable liposomes containing a bilayer fluidizing agent. Colloids Surf B Biointerfaces. 2009;72(1):155-160.

141. Yissum [website on the Internet]. Available from: http://www.yissum. co.il. Accessed November 14, 2015.

142. Sudhakar CK, Nitish U, Sanjay J, Charyulu RN. Ethosomes as noninvasive loom for transdermal drug delivery. In: Haghi AK, editor Nanomedicine and Drug Delivery. Oakville (ON): Apple Academic Press; 2012:1-16. 


\section{Publish your work in this journal}

The International Journal of Nanomedicine is an international, peerreviewed journal focusing on the application of nanotechnology in diagnostics, therapeutics, and drug delivery systems throughout the biomedical field. This journal is indexed on PubMed Central,

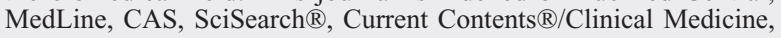

Journal Citation Reports/Science Edition, EMBase, Scopus and the Elsevier Bibliographic databases. The manuscript management system is completely online and includes a very quick and fair peer-review system, which is all easy to use. Visit http://www.dovepress.com/ testimonials.php to read real quotes from published authors.

Submit your manuscript here: http://www.dovepress.com/international-journal-of-nanomedicine-journal 